\title{
Synthesis of New Chiral Organosulfur Donors with Hydrogen Bonding Functionality and Their First Charge Transfer Salts.
}

Ismail Awheda, ${ }^{\text {a }}$ Sara J. Krivickas, ${ }^{\text {a }}$ Songjie Yang, ${ }^{\mathrm{a}}$ Lee Martin, ${ }^{\mathrm{a}}$ Milena A. Guziak, ${ }^{\mathrm{a}}$ Andrew C. Brooks,,${ }^{\mathrm{a}, \mathrm{b}}$ Frédéric Pelletier, ${ }^{\mathrm{a}}$ Melvyn Le Kerneau, ${ }^{\mathrm{a}}$ Peter Day, ${ }^{\mathrm{b}}$ Peter N. Horton, ${ }^{\mathrm{c}}$ Hiroki Akutsu, ${ }^{\mathrm{d}}$ John D. Wallis, ${ }^{\mathrm{a},}{ }^{,}$

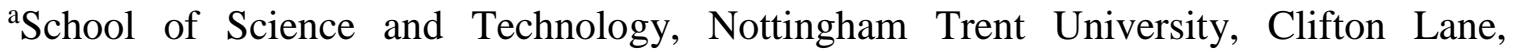
Nottingham NG11 8NS, UK; email: john.wallis@ntu.ac.uk

${ }^{\mathrm{b}}$ University College London, Department of Chemistry, 20 Gordon Street, London WC1H 0AJ, UK.

${ }^{\mathrm{c}}$ National Crystallography Service, Chemistry Department, University of Southampton, Highfield, Southampton SO17 1BJ,UK.

${ }^{d}$ Graduate School of Material Science, University of Hyogo, Kamigori-cho, Ako-gun, Hyogo, 678-1297, Japan.

\begin{abstract}
.
The syntheses of a range of enantiopure organosulfur donors with hydrogen bonding groups are described including TTF related materials with two, four, six and eight hydroxyl groups and multiple stereogenic centres and a pair of chiral $\mathrm{N}$-substituted BEDT-TTF acetamides. Three charge transfer salts of enantiopure poly-hydroxysubstituted donors are reported, including a 4:1 salt with the meso stereoisomer of the dinuclear $\left[\mathrm{Fe}_{2} \text { (oxalate) }\right]^{4-}$ anion in which both cation and anion have chiral components linked together by hydrogen bonding, and a semiconducting salt with triiodide.
\end{abstract}

Keywords: TTF, organosulfur donors, hydrogen bonding, chirality.

\section{Introduction}

TTF 1 and BEDT-TTF 2 have been at the forefront for the preparation of electrically conducting molecular systems, the former providing the first example of an organic metal in its complex with TCNQ, ${ }^{1}$ and the latter providing a large number of salts with varying 
electronic properties, including superconductivity. ${ }^{2}$ Considerable numbers of substituted derivatives of TTF and BEDT-TTF have been reported, ${ }^{3,4}$ and the former especially have found potential applications as molecular switches, ${ }^{5,6}$ sensors, ${ }^{5,7}$ field effect transistors ${ }^{8}$ and molecular electronics ${ }^{9}$ as well as in the preparation of conducting radical cation salts and fibres. ${ }^{10}$ Two recent research themes in this area have been the installation of chirality into the donor molecules and the attachment of groups with hydrogen bonding potential. The former is of importance following the discovery of magneto-chiral<smiles>C1=CSC(=C2SC=CS2)S1</smiles><smiles>CC1C[C@@H](C)SC2=C(SC(=C3SC4=C(SCCS4)S3)S2)S1</smiles>

4<smiles>C1CSC2=C(S1)SC(=C1SC3=C(SCCS3)S1)S2</smiles>

2<smiles></smiles>

5<smiles>CC1SC2=C(SC(=C3SC4=C(S3)S[C@H](C)[C@@H](C)S4)S2)SC1C</smiles>

3

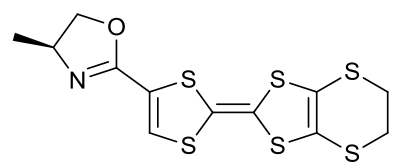

6<smiles>C[C@H](c1ccccc1)n1cc2c(c1)SC(=C1Sc3cn([C@H](C)c4ccccc4)cc3S1)S2</smiles>

7

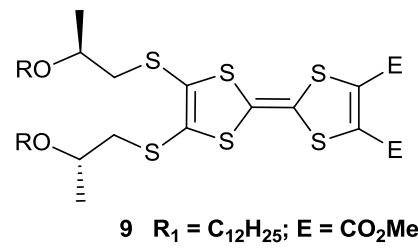<smiles>CCCCCCNC(=O)[C@H](CC(C)C)NC(=O)COCC1=CSC(=C2SC=CS2)S1</smiles>

11<smiles>OC[C@H]1SC2=C(SC(=C3SC4=C(SCCS4)S3)S2)S[C@@H]1CO</smiles>

13<smiles>CC1=C2SC3=C(SC(=C4SC5=C(SCCS5)S4)S3)SC2=C(C)[C@H]2CC[C@H]1C2</smiles>

8<smiles>[R]C1CCSC2=C(SCCC([R])C1)SC(=C1SC(SCCN)=C(SCCCN)S1)S2</smiles>

10<smiles>OCC1CSC2=C(SC(=C3SC4=C(SCCS4)S3)S2)S1</smiles>

12<smiles>OC[C@H](O)[C@H]1SC2=C(SC(=C3SC4=C(SCCS4)S3)S2)S[C@@H]1[C@H](O)CO</smiles> 
anisotropy in chiral conducting systems. ${ }^{11}$ The latter is important since hydrogen bonding with the anion in a salt, or between donors, can offer new organisations in the crystalline state. ${ }^{12}$ A range of enantiopure donors related to BEDT-TTF have been reported, including several with a stereogenic centre at a ring $\mathrm{C}$ or $\mathrm{S}$ atom e.g. 3-5, ${ }^{13,14}$ or external to the donor system as in $\mathbf{6 - 7 ^ { 1 5 , 1 6 }}$ as well as donors fused to a chiral pinene system e.g. $\mathbf{8}^{17}$ or incorporating a stereogenic axis from a 1-,1'-binaphthyl system. ${ }^{18}$ Examples of the latter have been investigated as redox sensitive chiroptical switches. ${ }^{19}$ Several simple TTF derivatives with chiral side chains have also been reported, e.g. 9-10 ${ }^{20}$ while Kato has combined 11 with an aromatic liquid crystal and an electron acceptor to provide fibrous conducting materials. ${ }^{21}$ Progress in these areas has been reviewed. ${ }^{22}$

A few<smiles>CC(O)CSC1=C(SCC(C)O)SC(=C2SC(SCC(C)O)=C(SCC(C)O)S2)S1</smiles>

15<smiles>OC[C@H](O)CSC1=C(SC[C@H](O)CO)SC(=C2SC(SC[C@H](O)CO)=C(SC[C@H](O)CO)S2)S1</smiles>

17<smiles>C[C@H](O)CSC1=C(SC[C@H](C)O)SC(=C2SC3=C(SCCS3)S2)S1</smiles>

16<smiles>OC[C@H](O)CSC1=C(SC[C@H](O)CO)SC(=C2SC3=C(SCCS3)S2)S1</smiles>

18<smiles>C[C@H](O)CSC1=C(SC[C@@H](C)O)SC(=C2SC(SC[C@H](O)CO)=C(SC[C@H](O)CO)S2)S1</smiles>

19

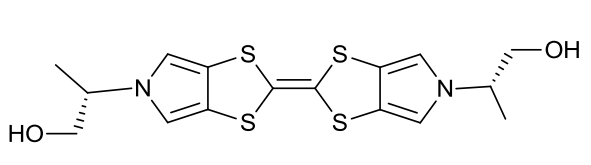

20

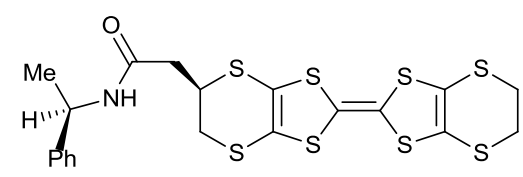

22

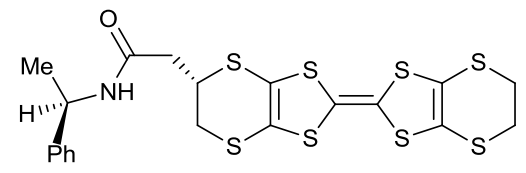

21<smiles>O=C(O)C[C@H]1SC2=C(SC(=C3SC4=C(SCCS4)S3)S2)S[C@@H]1CC(=O)O</smiles>

rac-23 
enantiopure donors with hydrogen bonding functionality have been reported e.g. BEDTTTF derivatives $\mathbf{1 2 - 1 4},{ }^{23}$ as well as a series of peptide derivatives and a $D$-glucose derived material. ${ }^{24}$ Here we report the preparation of new donors 15-22 which are both enantiopure and include hydroxyl or amide groups capable of forming hydrogen bonds, as well as progress towards making trans-BEDT-TTF diacid 23 as a racemate.

\section{Results and Discussion.}

\section{Synthesis of chiral TTF-related polyols 15-20.}
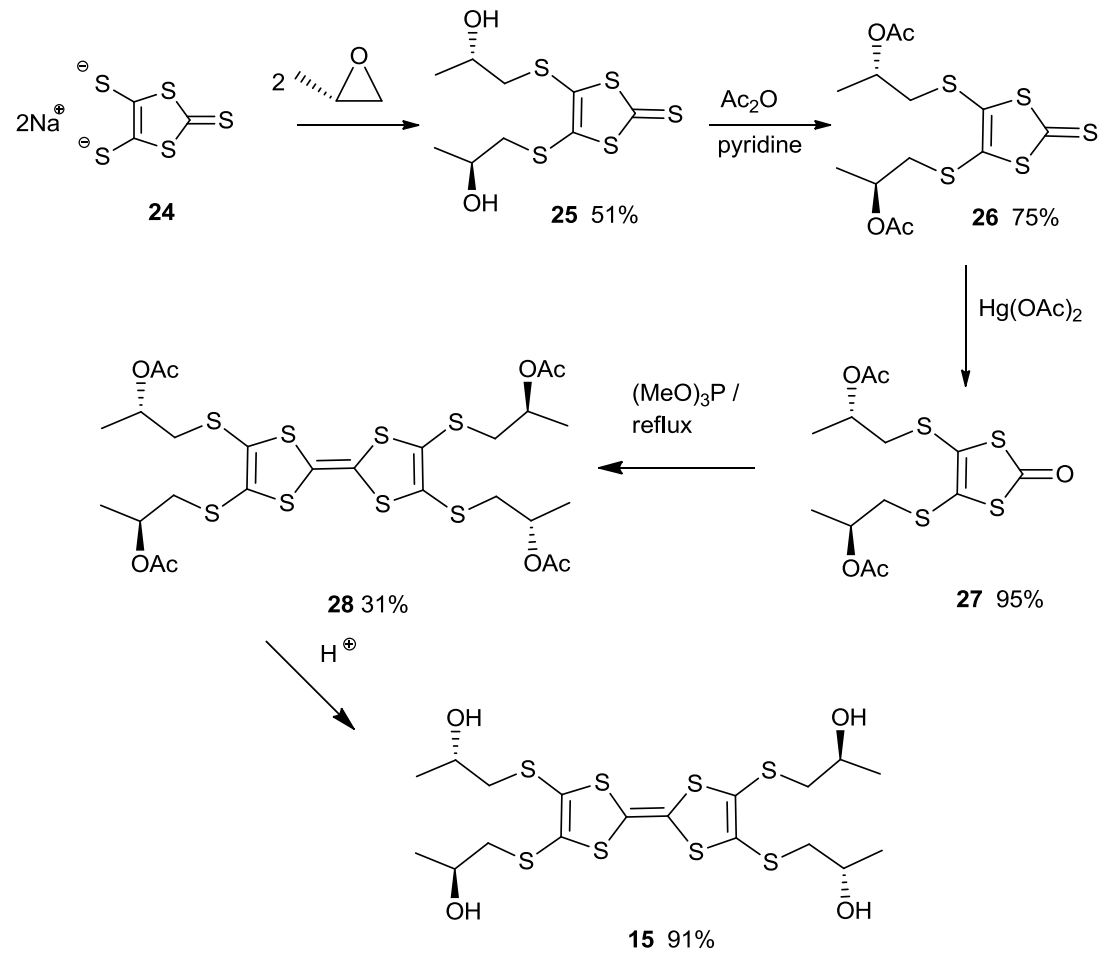

Scheme 1.

As a first step to provide donors with both chirality and hydrogen bonding potential, two TTF derivatives with 2-hydroxypropylthio side-chains which had a hydroxyl group at a stereogenic centre were targeted (Scheme 1). Reaction of dithiolate $24^{25}$ with two equivalents of $(S)$-methyloxirane gave the thione 25 containing two chiral 2hydroxypropylthio side-chains in $51 \%$ yield. The synthesis was continued by protection of the hydroxyl groups by acetylation to give $\mathbf{2 6}$ and exchange of the thione sulfur for oxygen using mercuric acetate to give the oxo compound $\mathbf{2 7}$ in $71 \%$ yield from thione $\mathbf{2 5}$. 
Homo-coupling of 27 in refluxing trimethyl phosphite for 24 hours gave the chiral Oprotected donor $\mathbf{2 8}$ in $31 \%$ yield which was then hydrolysed to the chiral tetrol $\mathbf{1 5}$ in 91\% yield. The chiral oxo compound 27 was also cross-coupled with the unsubstituted thione 29 to give the disubstituted donor $\mathbf{3 0}$ in $43 \%$ yield, which was subsequently hydrolysed to the diol 16 in $94 \%$ yield (Scheme 2). The $R, R$ enantiomer of 16 was prepared in a similar way starting from $(R)$-methyloxirane. The attempted synthesis of the meso- $(R, S)$-isomer of $\mathbf{1 6}$ from rac-methyloxirane led to unseparable mixtures of meso and racemic $(R, R)$ compounds at each step. The racemate is most easily made by mixing equimolar amounts of the two enantiomers. The crystal structure of donor 15 (Fig. 1) shows that one pair of chains form an internal hydrogen bond while both make further intermolecular interactions so that the donors and side-chains are more or less segregated in the crystal packing. ${ }^{26}$
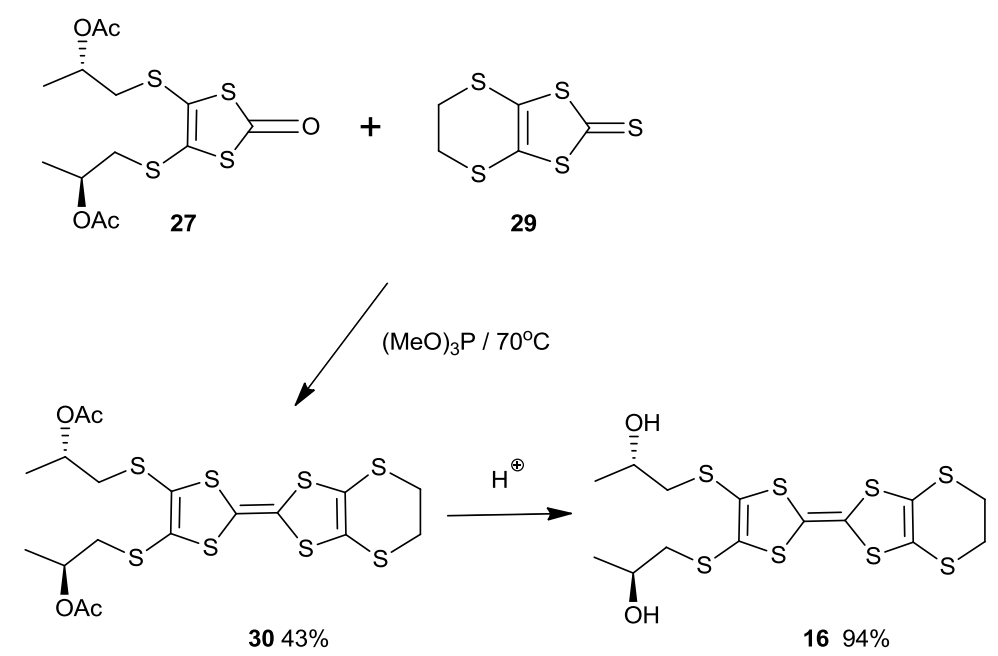

Scheme 2. 


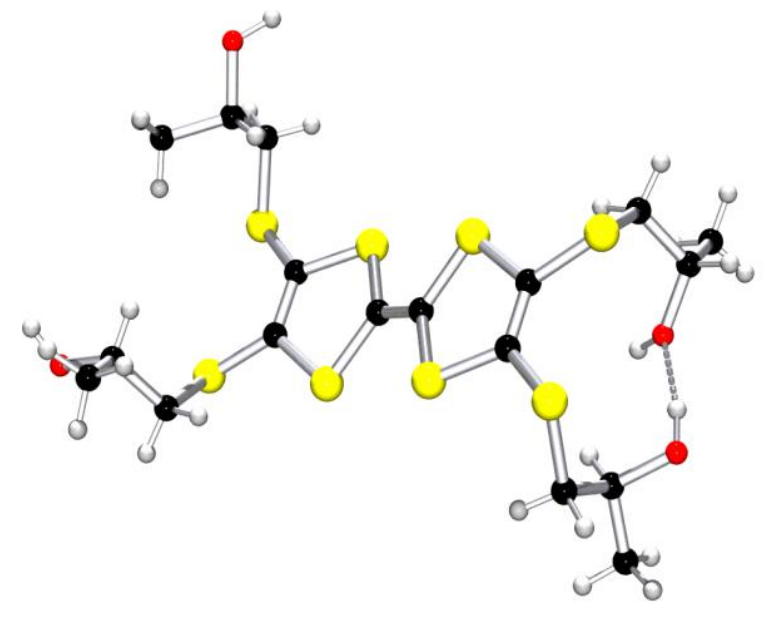

Figure 1. Molecular structure of $\mathbf{1 5}$, showing the hydrogen bond between two side chains.
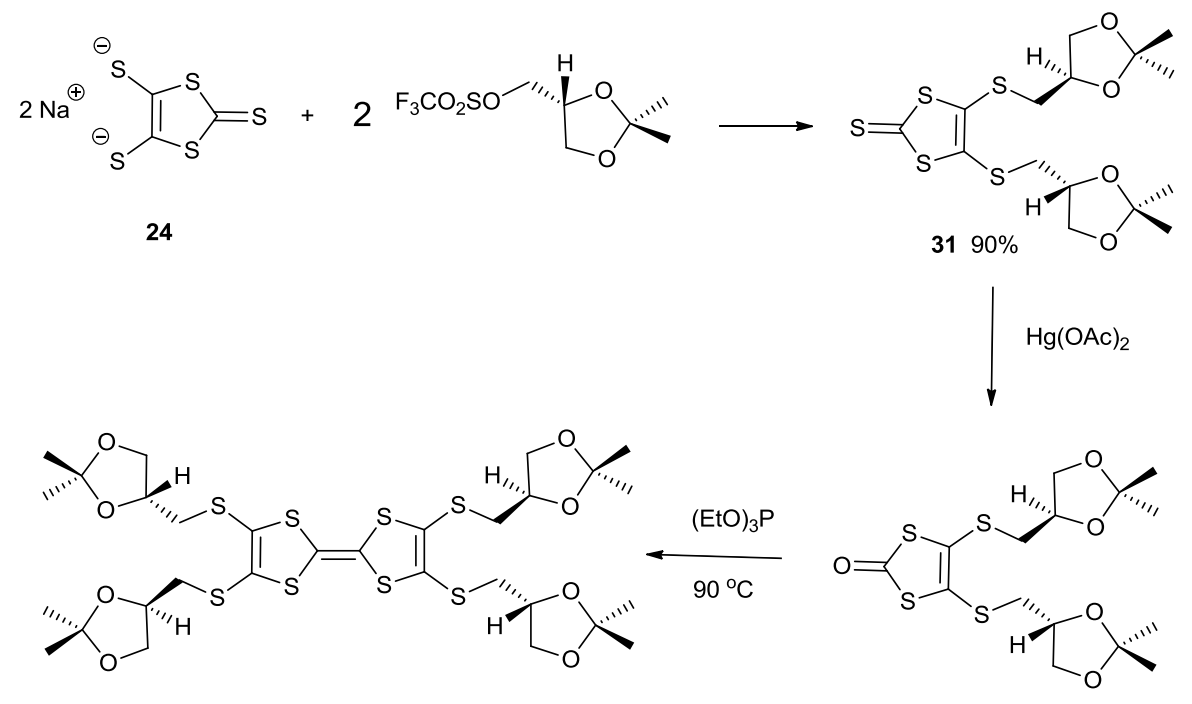

$3351 \%$

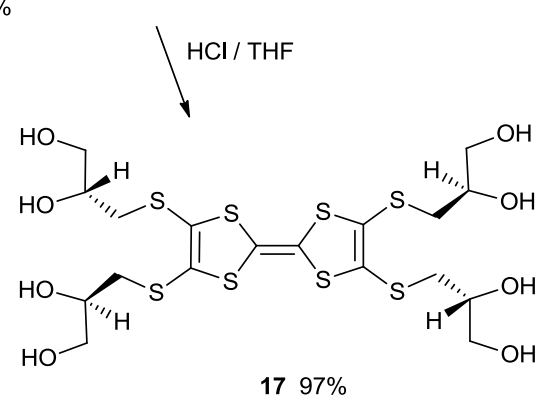

$3293 \%$

Scheme 3. 
Introduction of hydroxyl groups on to the terminal methyl groups of these two would provide donors $\mathbf{1 7}$ and $\mathbf{1 8}$ with additional sites for hydrogen bonding or for extension of the side chains. The synthesis of these materials (Scheme 3) was achieved by reaction of the dithiolate 24 with two equivalents of the triflate of $(S)$-1,2-isopropylidene-glycerol to give the thione $\mathbf{3 1}$ in $90 \%$ yield. Neither the corresponding mesylate nor tosylate were effective for this reaction. The symmetrical donor 17 was then prepared in three steps by conversion of thione 31 to the oxo compound 32, homo-coupling in triethyl phosphite to give the tetra(ketal) donor $\mathbf{3 3}$ in $51 \%$ yield and then almost quantitative deprotection of the diol groupings using $\mathrm{HCl}$ in THF. The unsymmetrical donor $\mathbf{1 8}$ was prepared by cross coupling of the oxo compound 32 with the thione 29 to give the donor $\mathbf{3 4}$ in $60 \%$ yield after chromatography, which was deprotected to give the tetrol $\mathbf{1 8}$ in $95 \%$ yield (Scheme 4). To provide a donor with different chirally disposed hydrogen bonding functionality at either end, the donor 19 was prepared which at one end had two $(R)$-2hydroxypropylthio side chains and at the other end two $(R)$-2,3-dihydroxypropylthio side chains (Scheme 5). This was achieved by reacting the $R, R$-enantiomer of bis(acetoxy) thione 26 with the bis ketal-protected oxo compound $\mathbf{3 2}$ in triethyl phosphite to give the

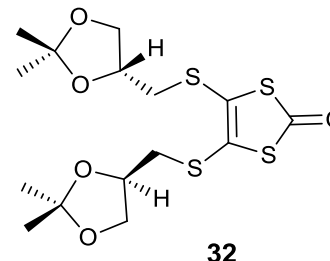

32

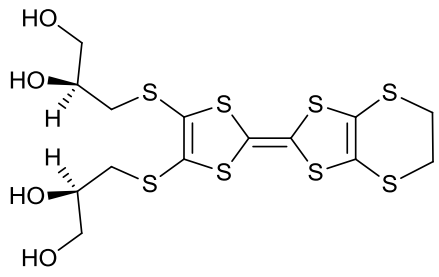

$1895 \%$

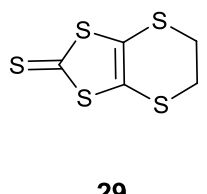

29

$\mathrm{HCl} / \mathrm{THF}$

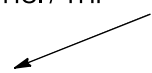

$3460 \%$

Scheme 4. 
O-protected hexol 35 in 30\% yield after chromatography to separate from homo-coupled species. Removal of the acetyl protecting groups with aqueous potassium carbonate gave the dihydroxy donor 36, and the ketal groups were hydrolysed by subsequent treatment with $\mathrm{HCl}$ in THF to yield the unsymmetrical chiral hexol donor $\mathbf{1 8}$ with two different pairs of hydroxyl substituted stereogenic centres.

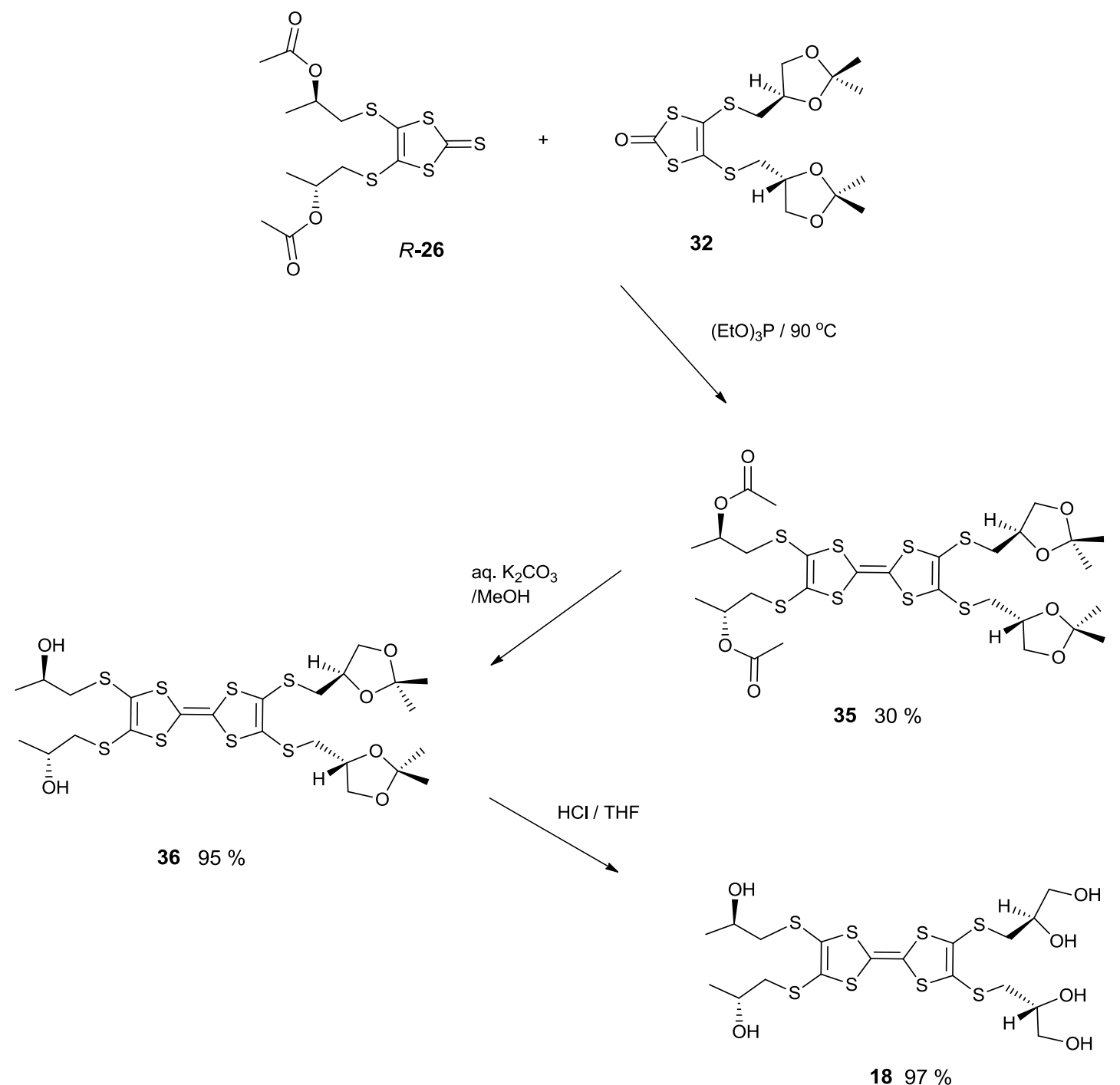

Scheme 5 . 


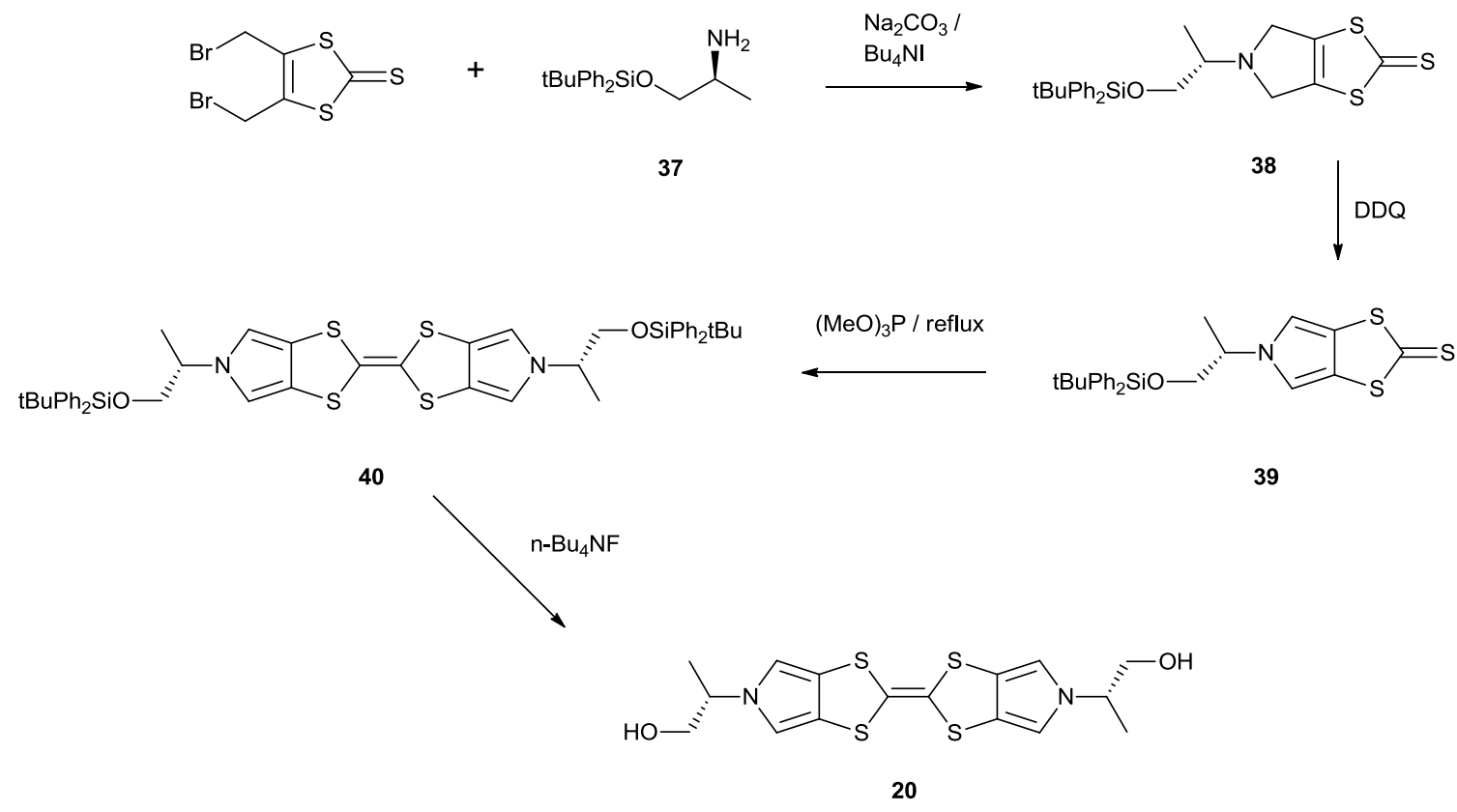

Scheme 6.

To prepare a donor with one chiral hydrogen bonding side chain at each end, the approach of Becher to make bis(pyrrolo)TTFs ${ }^{27,28}$ was taken, an approach which has already yielded the chiral donor 7. ${ }^{16}$ Thus the donor 20, a bis(pyrrolo)tetrathiafulvalene bearing $2 S$-2-(1-hydroxy)propyl substituents attached to each nitrogen atom, was chosen as a target (Scheme 6). The synthesis started from $(S)-(+)-2$-amino-1-propanol, by $O$ protection with a t-butyldiphenylsilyl group to give amine $37,{ }^{29}$ which was reacted with bis(bromomethyl)-1,3-dithiolethione ${ }^{28}$ in the presence of sodium carbonate and tetrabutylammonium iodide to give the dihydropyrrole derivative $\mathbf{3 8}$ which was directly oxidized with DDQ in benzene at $c a-10^{\circ} \mathrm{C}$ to give the dithiolo(4,5-c)pyrrole thione 39 in $53 \%$ overall yield after chromatography. Prolonged reflux of thione 39 with freshly distilled trimethyl phosphite gave the corresponding bis(pyrrolo)tetrathiafulvalene $\mathbf{4 0}$ in $32 \%$ yield. Deprotection of the hydroxyl groups was carried out using tetrabutylammmonium fluoride in THF at room temperature to give the desired chiral donor $\mathbf{2 0}$ functionalised with two hydroxyl groups in 50\% yield. 


\section{Synthesis of enantiopure amides 21 and 22.}

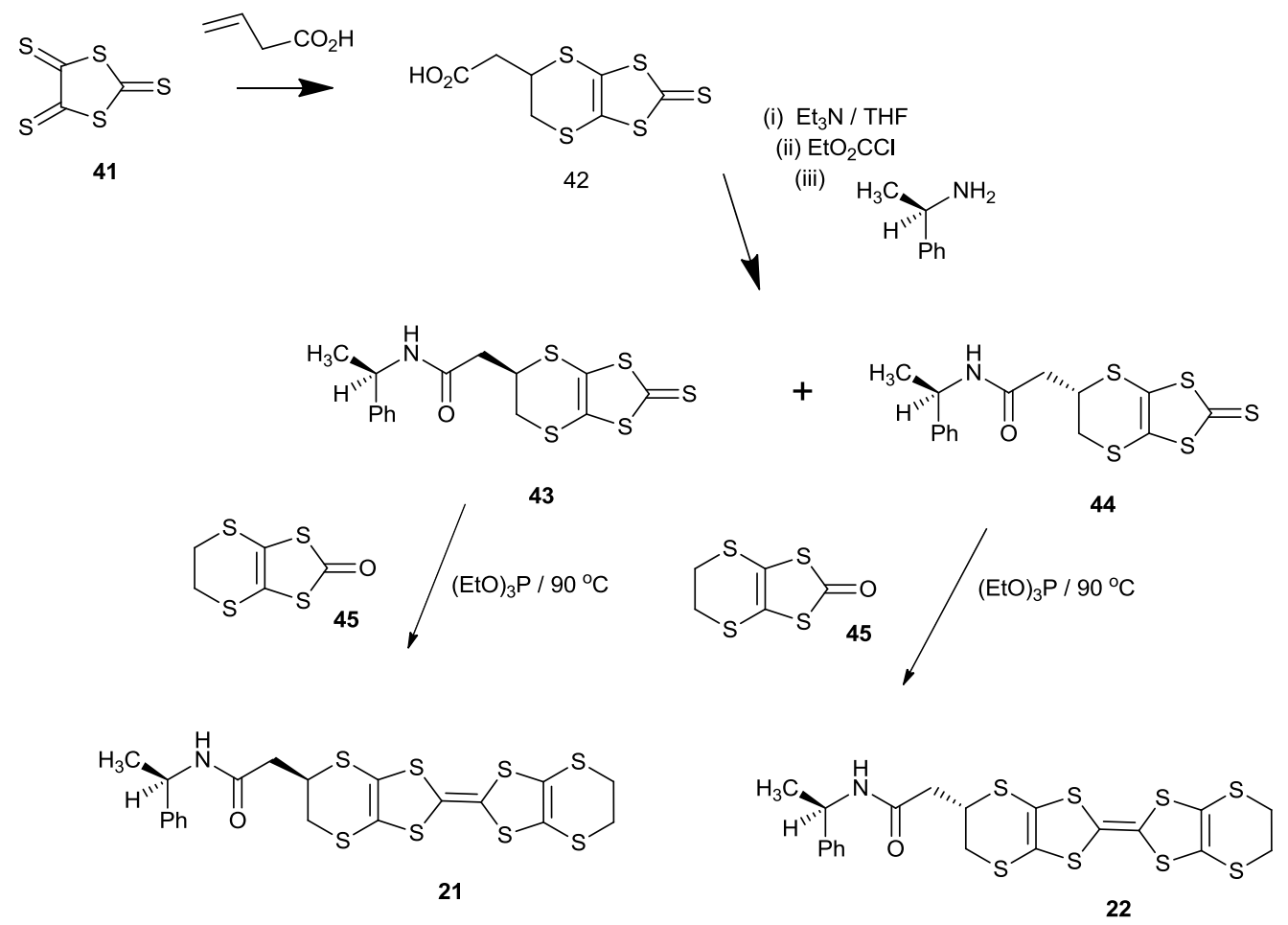

Scheme 7.

There is only one monosubstituted BEDT-TTF which has been prepared as a pure enantiomer, the hydroxymethyl derivative, but the route is eight steps from $(S)-1,2-$ isopropylideneglycerol. With a view to resolving the chirality at the stereogenic centre on a BEDT-TTF derivative in a shorter sequence we have taken an approach to deliberately prepare diastereomers which can then be separated, in this case by modification of our synthesis of the racemic BEDT-TTF derivatives bearing a functionalised acetamide side chain $\left(-\mathrm{CH}_{2} \mathrm{CONHR}\right){ }^{30}$ Trithione $\mathbf{4 1}^{25}$ was reacted with vinylacetic acid to give the bicyclic carboxylic acid 42, which was then converted to two diastereoisomeric amides $\mathbf{4 3}$ and $\mathbf{4 4}$ by formation of the mixed anhydride with ethyl chloroformate followed by reaction with the enantiopure amine $R$ - $\alpha$-phenylethylamine. The two isomeric amides were separated by chromatography and obtained in similar yields of $c a$. 28\%, and the structure of $\mathbf{4 4}$ was confirmed by X-ray crystallography to have the $S$ configuration at 5-C (Fig. 2). The main difference in their ${ }^{1} \mathrm{H}$ NMR spectra is 
between the signals from the side chain methylene groups, which in 43 appears as a doublet at $\delta: 2.71 \mathrm{ppm}$, but in $\mathbf{4 4}$ appears as two doublet doublets at $\delta: 2.63$ and 2.71 ppm. Both thiones were cross coupled with the unsubstituted oxo compound $\mathbf{4 5}$ in triethyl phosphite at $90^{\circ} \mathrm{C}$ to give the corresponding chiral donors 21 and 22 in 31 and $46 \%$ yields respectively. Attempts to convert these new donors to the enantiomers of primary amide BEDT-TTF- $\mathrm{CH}_{2} \mathrm{CONH}_{2}$ have been unsuccessful. However, these donors are likely to be better substrates for investigating the influence of chirality on conductivity since the two enantiomers of the primary amide can adopt similar shapes by the substituted dithiin ring adopting the particular envelope conformation which places the side chain in a pseudo-equatorial position.

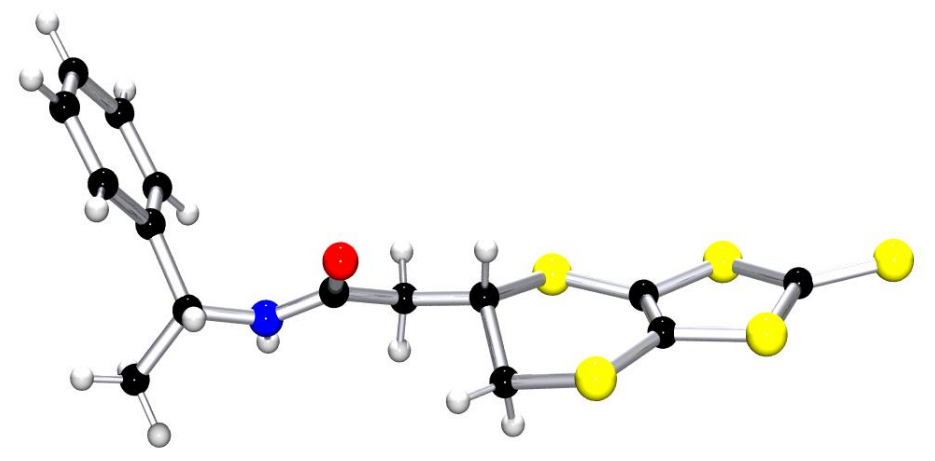

Figure 2. Molecular structure of diastereomer 44 with $(S)$ stereochemistry at 5-C on the dithiin ring.

\section{Synthesis of the racemic trans-diacid 23.}
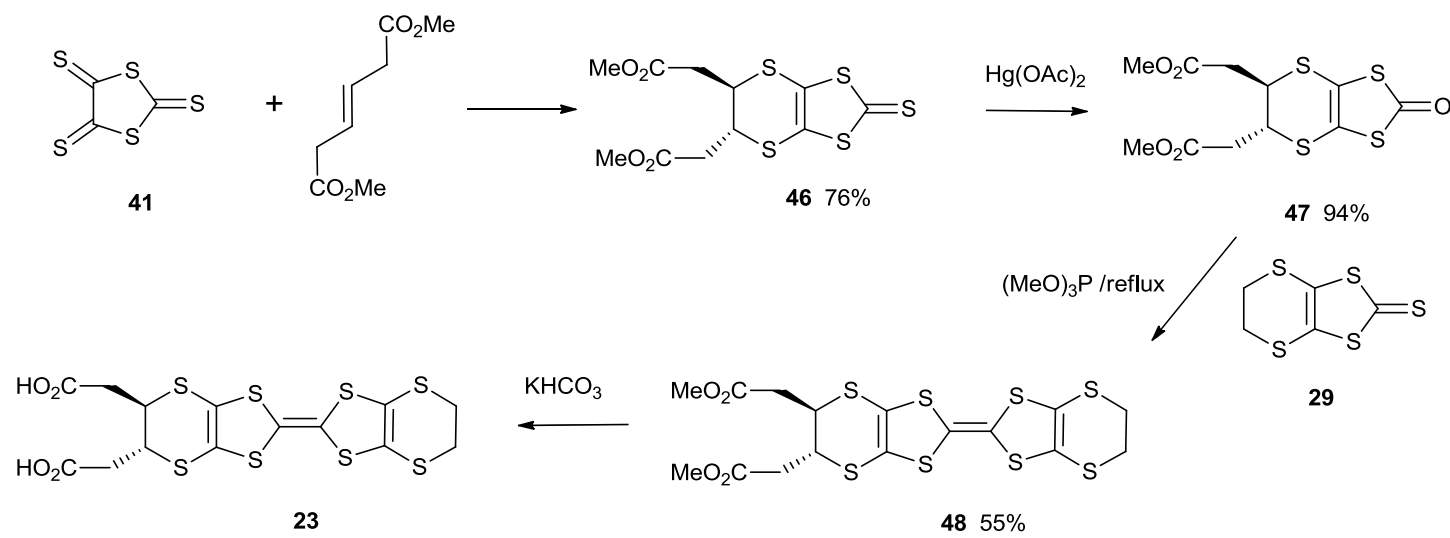

29

Scheme 8. 
Carboxylic acid groups are also potential hydrogen bonding centres, as well as precursors of other functionalities. The only such BEDT-TTF derivative reported is the mono $\mathrm{CH}_{2} \mathrm{CO}_{2} \mathrm{H}$ derivative, which has very limited solubility in typical organic solvents. So we examined routes to an enantiomer of the trans bis-acid 23. Attempted synthesis from dimethyl 3,4-dihydroxyhexandioate failed when the derived cyclic sulfate ester could not be cyclised with the dithiolate 24. The enantiomers of such trans-disubstituted BEDTTTFs have been difficult to prepare, for example trans-BEDT-TTF-bis(methanol) was only prepared in enantiopure form by chiral chromatography. ${ }^{13}$ We thus attempted the synthesis of the racemate of bis-acid 23. Reaction of dimethyl E-hex-3-en-1,5-dioate with the trithione 41 in refluxing toluene gave the thione $\mathbf{4 6}$ with trans oriented side chains in $76 \%$ yield. Reaction of the thione $\mathbf{4 6}$ with mercuric acetate gave the oxo compound $\mathbf{4 7}$ in 94\% yield, the cross-coupling of which with the unsubstituted thione $\mathbf{2 9}$ gave the trans disubstituted donor 48 in $55 \%$ yield. (Homo-coupling of 47 in trimethyl phosphite at $120{ }^{\circ} \mathrm{C}$ gave the tetrasubstituted BEDT-TTF in $81 \%$ yield as a mixture of a racemate and a meso compound.) Hydrolysis of the diester $\mathbf{4 8}$ with potassium hydrogen carbonate in a water/methanol/THF mixture followed by acidification give a solid the composition of which corresponds to a 1:1 mixture of the diacid 23 and its monopotassium salt.

To extend this chemistry, oxo compound 47 was cross-coupled with thione 49 , the adduct of norbornene and trithione 41. The latter is formed very readily and exclusively as the exo-adduct in $95 \%$ yield, and its stereochemistry was confirmed by X-ray crystallography. ${ }^{26}$ The cross coupled product was produced as a 1:1 mixture of two diastereomers $\mathbf{5 0}$ and $\mathbf{5 1 .}$ 
<smiles>S=C1SC(=S)C(=S)S1</smiles>

41<smiles>C1=CC2CC1C2</smiles><smiles>C1CCC1</smiles><smiles>C1CCCC1</smiles><smiles>S=c1sc2c(s1)SC1C3CCC(C3)C1S2</smiles>

$4995 \%$

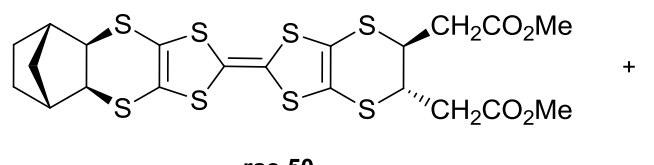

$36 \%$<smiles>COCC[C@H]1SC2=C(SC(=C3SC4=C(S3)[C@@H]3S[C@@H](S4)C4CCC3C4)S2)S[C@@H]1CC(C)=O</smiles>

rac-51

Scheme 9.

\section{Charge Transfer Salts.}

Table 1. Cyclic voltammetry data for electron donors ${ }^{\mathrm{a}}$.

\begin{tabular}{|l|l|l|}
\hline Donor & $\mathrm{E}_{1}(\mathrm{~V})$ & $\mathrm{E}_{2}(\mathrm{~V})$ \\
\hline & & \\
$\mathbf{1 5}$ & 0.50 & 0.76 \\
$\mathbf{1 6}$ & 0.48 & 0.80 \\
$\mathbf{1 7}^{\mathrm{b}}$ & 0.68 & 0.83 \\
$\mathbf{1 8}^{\mathrm{b}}$ & 0.71 & 0.85 \\
$\mathbf{1 9}^{\mathrm{b}}$ & 0.69 & 0.83 \\
$\mathbf{2 1}$ & 0.56 & 0.95 \\
$\mathbf{2 2}$ & 0.52 & 0.91 \\
$\mathbf{3 3}$ & 0.59 & 0.89 \\
$\mathbf{3 4}$ & 0.59 & 0.92 \\
$\mathbf{3 5}$ & 0.61 & 0.92 \\
$\mathbf{3 6}$ & 0.58 & 0.86 \\
$\mathbf{4 8}$ & 0.58 & 0.97 \\
$\mathbf{5 0 / 5 1}$ & 0.57 & 0.96 \\
& & \\
\hline
\end{tabular}

${ }^{\mathrm{a}}$ Measured relative to $\mathrm{Ag} / \mathrm{AgCl}$ at a platinum electrode in dichloromethane containing 0.1 $\mathrm{M} n-\mathrm{Bu}_{4} \mathrm{NPF}_{6}$ as charge carrier and using a $100 \mathrm{mV} \mathrm{s}^{-1}$ scan, ${ }^{\mathrm{b}} \mathrm{THF}$ used as solvent.

The oxidation potentials of the novel donors show two oxidation potentials similar to those of BEDT-TTF and tetra(methylthio)TTF (Table 1), though the donors with side-chains containing diols, 17-19, are notably higher, possibly a reflection of a 
non-reversible interaction with the electrode. Here we report the first results for preparing charge transfer materials from enantiopure donors 16 and 18. Diol 16 forms a salt with the $\mathrm{Fe}(\mathrm{III})_{2}$ (oxalate $)_{5}$ tetraanion by electrocrystallisation with the ammonium salt of racemic iron(III)tris(oxalate) and a molecular complex with tetrafluoro-TCNQ. Tetrol 18 forms a 1:1 salt with triiodide. In the crystals of the oxalate salt (monoclinic, P2 ${ }_{1}$ ) the asymmetric unit contains four donor molecules and one $\mathrm{Fe}(\mathrm{III})_{2}(\text { oxalate })_{5}{ }^{4-}$ species in which one oxalate bridges between the two iron atoms which thus retain coordination numbers of six (Fig. 3). The chirality at the two metal centres in the anion are opposite ( $\Delta$ and $\Lambda$ ), nevertheless this is the first report of a charge transfer salt with a source of chirality in both the donor and the anion components. Charge transfer salts of this anion with TTF and BEDT-TTF have been reported. ${ }^{31}$ The accuracy of the bond lengths is not sufficient for application of the empirical method for estimating each donor's oxidation state to determine whether the net charge of +4 is equally distributed or not. ${ }^{32}$ The crystal structure contains alternate layers of donors and anions, with donors stacking within the layer. The eight terminal $\mathrm{O}$ atoms of the anion form seven hydrogen bonds to hydroxyl groups belonging to donor molecules, and there is just one crystallographically unique hydrogen bond between donor molecules, and it bridges between stacks. The bridging oxalate residue is not involved in any hydrogen bonding. Reproducible two probe resistivity measurements were not possible due to the fragility of the tiny crystals.

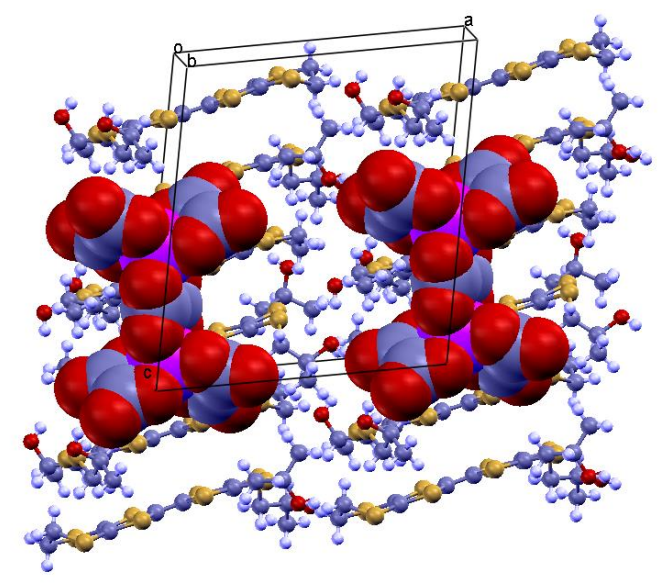

Figure 3. Crystal packing arrangement of (16) ${ }_{4} \mathrm{Fe}_{2}$ (oxalate) $)_{5}$ viewed along $b$, perpendicular to the successive layers of anions and donor cations. 
The crystal structure of the 1:1 complex with $\mathrm{TCNQ}^{-\mathrm{F}_{4}}$ is quite different (Fig. 4). The donors and acceptors are both packed in face-to-face pairs with one pair of donors and one pair of acceptors in the unit cell (triclinic, P1). The donor pairs are packed head to tail with four short S---S contacts between sulfur atoms of the opposing TTF units (3.339-3.354 $\AA$ ), and the average bond lengths in the TTF cores indicate that the donor is a monocation. ${ }^{32}$ The material is thus best considered as a salt. The pairs of donors and acceptors form layers in the $b . a-c$ plane, with the best planes of the TTF cores of the donors and the TCNQ-F $\mathrm{F}_{4}$ acceptors lying at $c a 65^{\circ}$ to each other. There are O-H---F hydrogen bonds between the layers (Fig. 4). Although there is no stacking between the donor pairs, there are two S---S side to side contacts between donor pairs (3.545-3.579 $\AA)$. The material is an insulator: multiple crystals measured showed room temperature resistances higher than the measurement upper limit of the equipment ( $>1 \times 10^{7} \mathrm{Ohms}$ ).

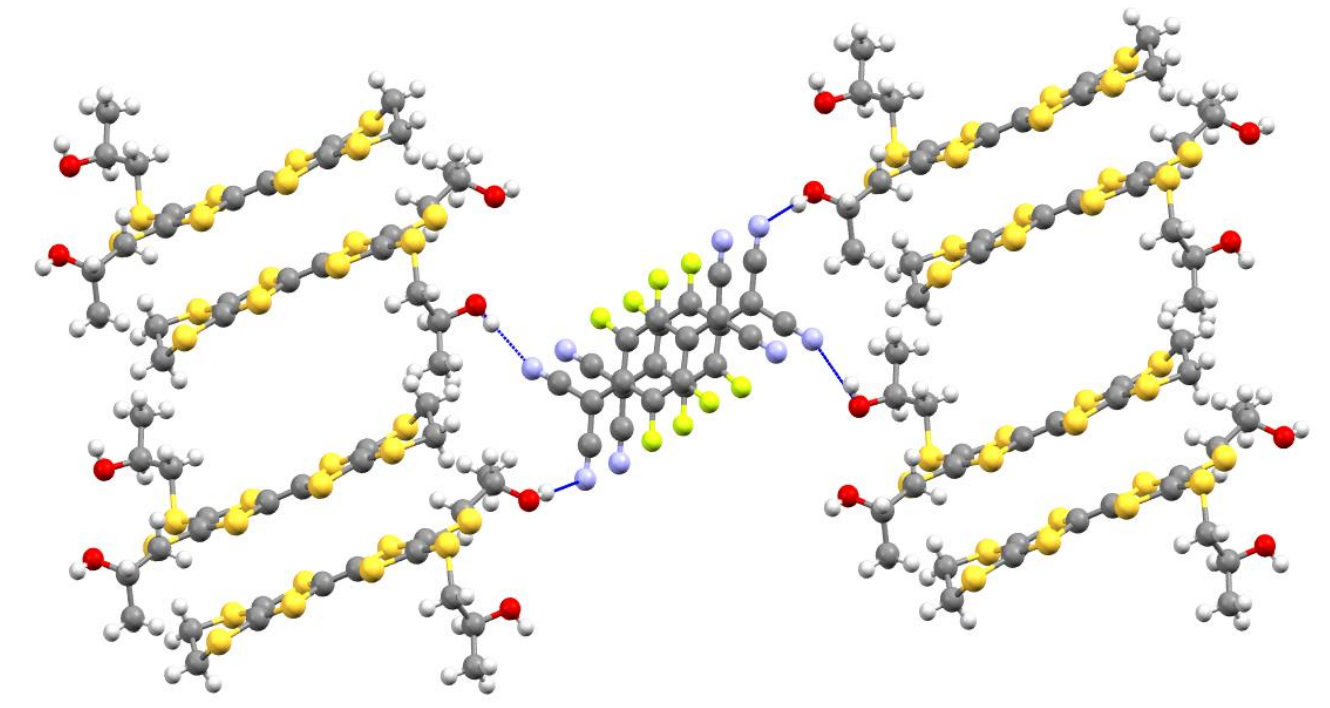

Figure 4. Hydrogen bonding between the TCNQ-F 4 molecules in one layer and molecules of donor 16 in adjacent layers, showing pairing of donor molecules. Donor pairs in the central layer are omitted for clarity.

Diffusion of iodine into a DCM solution of chiral tetrol 18 gave crystals of a 1:1 salt with $\mathrm{I}_{3}^{-}$the structure of which was determined by X-ray crystallography at $150 \mathrm{~K}$. Donor monocations are organised in 'face to face pairs' with side chains at opposite ends 
of the pair and directed away from the other donor (Fig. 5). Triiodides are organised in 'end to end' linear pairs with the I...I contact between them being one of the shortest reported $(3.422 \AA)$. There are six short $S \cdots S$ contacts $(3.365-3.480 \AA)$ within the pair of donors, and two sets of intermolecular hydrogen bonds: one between secondary hydroxyl groups, and a roughly square array involving four primary hydroxyl groups with a 1:1 disorder in the positions of the hydrogen atoms around the square of oxygen atoms, with either arrangement breaking the symmetry of the two-fold axis which cuts the square. The salt is semiconducting with a room temperature resistivity of $3.61 \mathrm{ohm} \mathrm{cm}$ with an activation energy of $22.5 \mathrm{meV}$ and show hysteresis in the range $60-250 \mathrm{~K}$ on cooling and rewarming (Fig. 6). This may be related to the disordered hydrogen bonding square arrangement which may prefer just one of the two possible arrangements at low temperature $(<60 \mathrm{~K})$, and this is maintained on warming until ca $250 \mathrm{~K}$.

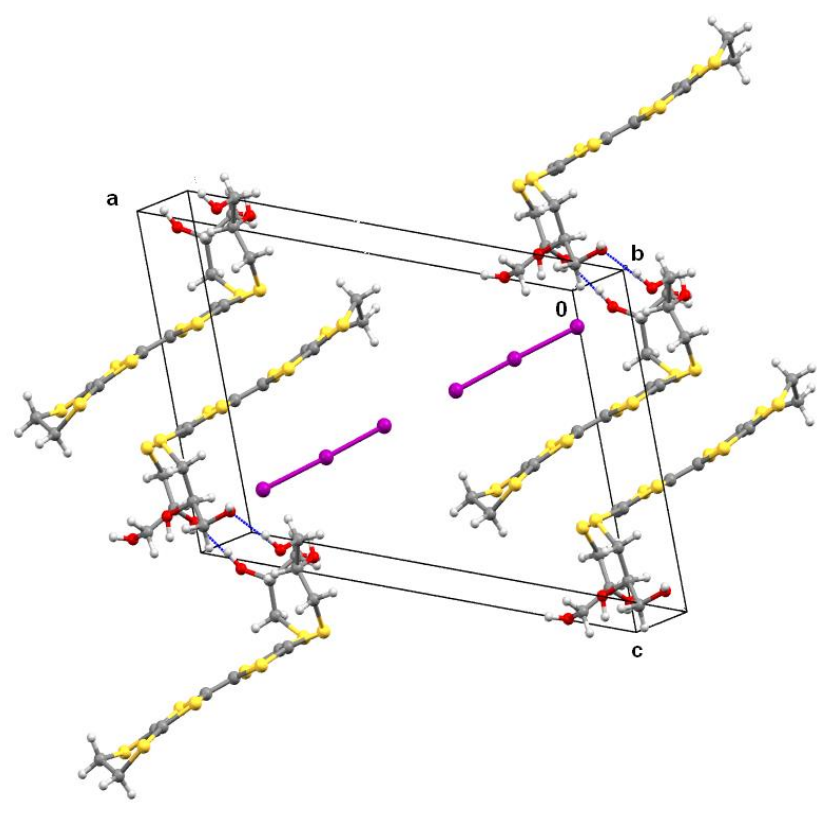




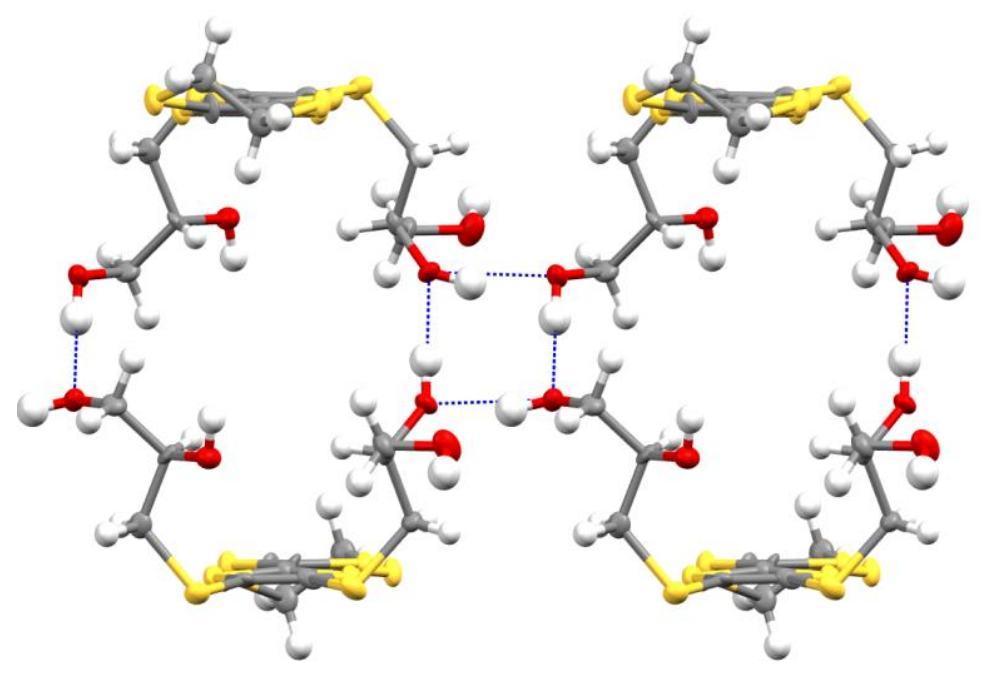

Figure 5. Crystal packing arrangement of 18. I $_{3}$ showing the end to end triiodide pair and donor cation pairs (top), and four primary hydroxyl groups hydrogen bonding together in a square formation, in which just one of two sets of hydrogen atom positions is shown (below).

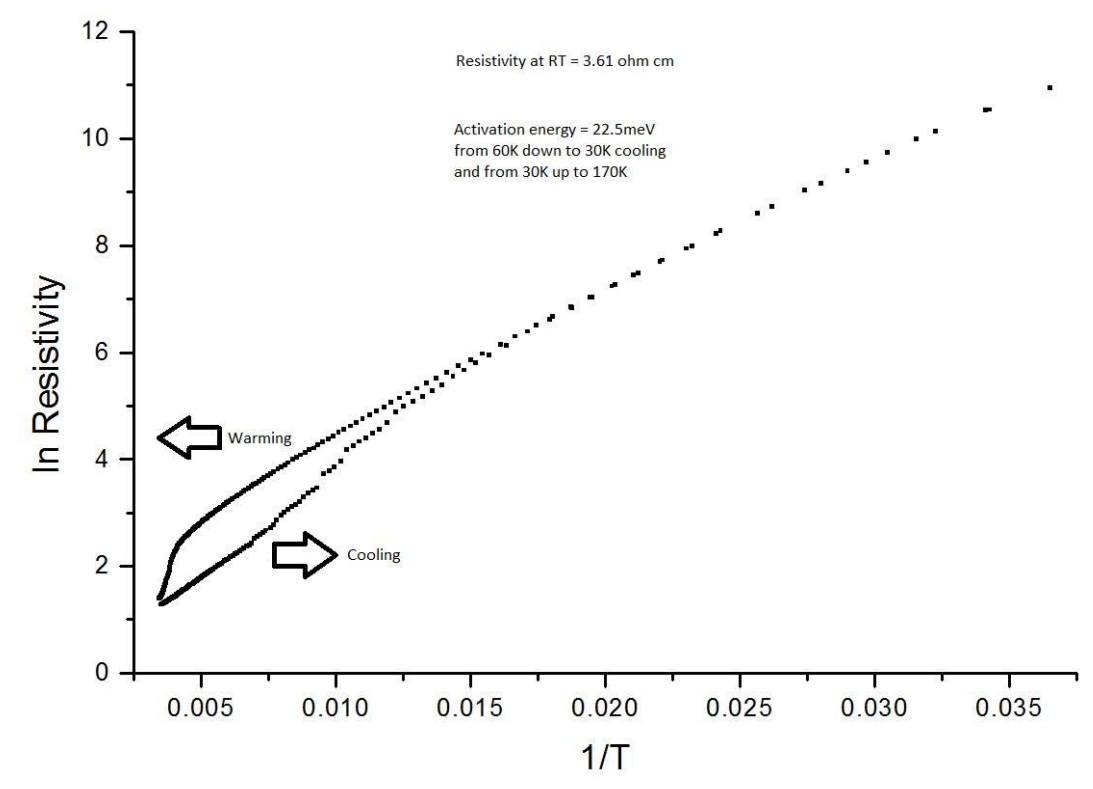

Figure 6. Plot of $\ln$ (Resistivity) vs $1 / \mathrm{T}$ for $18 . \mathrm{I}_{3}$ showing hysteresis between 60 and 250 K. 


\section{Conclusion.}

A new range of symmetrically and unsymmetrically substituted enantiopure donors with hydrogen bonding potential are now available. The challenge now is to prepare conducting systems from them and see how their chirality moderates their electromagnetic properties by a comparison of the properties of products prepared from opposite enantiomers. Electrocrystallisation studies and diffusion experiments with electron deficient species are underway to build on the salts prepared here in which hydrogen bonding plays an important role in their physical properties. 
Experimental. General. NMR spectra were measured on a JEOL ECLIPSE 400 spectrometer at $400 \mathrm{MHz}$ for ${ }^{1} \mathrm{H}$ and at $100.6 \mathrm{MHz}$ for ${ }^{13} \mathrm{C}$ using $\mathrm{CDCl}_{3}$ as solvent and tetramethylsilane (TMS) as standard unless otherwise stated, and measured in p.p.m. downfield from TMS with coupling constants reported in Hz. IR spectra were recorded on Perkin Elmer Spectrum 100 FT-IR Spectrometer using an ATR window, and are reported in $\mathrm{cm}^{-1}$. Raman measurements were made on a Foster and Freeman Foram 685-2 spectrometer, with excitation at $685 \mathrm{~nm}$ and are reported in $\mathrm{cm}^{-1}$. Solid-state uv/visible spectra was measured using a JASCO V-670 instrument. Optical rotation data were measured on a PerkinElmer 241 polarimeter at the sodium D-line. Mass spectra were recorded at the EPSRC Mass Spectrometry Centre at the University of Swansea. Chemical analysis data were obtained from Mr Stephen Boyer, London Metropolitan University. X-ray diffraction datasets were measured by the EPSRC National Crystallography Service at Southampton University. Flash chromatography was performed on 40-63 silica gel (Merck).

\section{Bis((2'S)-2'-hydroxylpropylthio)-1,3-dithiole-2-thione 25.}

A solution of disodium dithiolate $\mathbf{2 4}$ in dry methanol (300 $\mathrm{ml}$ ), prepared in situ from 4,5bis(benzoylthio)-1,3-dithiol-2-thione (17.5 g, $43.0 \mathrm{mmol}$ ) and sodium methoxide (4.66 g, $86 \mathrm{mmol})$ under a nitrogen atmosphere, ${ }^{25}$ was treated with $(S)$-(-)-propylene oxide $(5.0 \mathrm{~g}$, $86.0 \mathrm{mmol}$ ) at room temperature. The deep purple solution turned orange-red over several minutes, and the mixture stirred at room temperature for $5 \mathrm{~h}$. Acetic acid $(10 \mathrm{ml})$ was added. After stirring for $1 \mathrm{~h}$, the reaction mixture was concentrated in vacuo, the methyl benzoate removed by Kugelrohr distillation, and the residue was purified by flash chromatography $\left(\mathrm{SiO}_{2}\right.$, eluting with cyclohexane:ethyl acetate 2:1) to yield 25 (6.90 g, $51.0 \%)$ as a red brown oil; $\mathrm{R}_{\mathrm{f}}$ (cyclohexane:ethyl acetate 2:1) $0.26 ; \delta_{H}\left(400 \mathrm{MHz}, \mathrm{CDCl}_{3}\right.$ ) $3.90(2 \mathrm{H}, \mathrm{m}, 2 \times \mathrm{CHOH}), 3.23(2 \mathrm{H}, \mathrm{br}, 2 \times \mathrm{OH}), 2.99\left(2 \mathrm{H}, \mathrm{dd}, \mathrm{J} 3.6,13.8 \mathrm{~Hz}, 2 \times \mathrm{C} H_{\alpha} \mathrm{S}\right)$, $2.78\left(2 \mathrm{H}, \mathrm{dd}, \mathrm{J} 8.4,13.8 \mathrm{~Hz}, 2 \times \mathrm{CH}_{\beta} \mathrm{S}\right), 1.24\left(6 \mathrm{H}, \mathrm{d}, \mathrm{J} 6.2 \mathrm{~Hz}, 2 \times \mathrm{CH}_{3}\right) ; \delta_{C}(100.6 \mathrm{MHz}$, $\left.\mathrm{CDCl}_{3}\right) 210.6(\mathrm{C}=\mathrm{S}), 136.6(4-, 5-\mathrm{C}), 66.1(2 \times \mathrm{CHOH}), 45.4\left(2 \times \mathrm{CH}_{2} \mathrm{~S}\right), 22.0\left(2 \times \mathrm{CH}_{3}\right)$; $v_{\max }: 3342,2967,2919,1724,1455,1399,1372,1240,1188,1123,1058,1035,934,892$, 
816, 516, 451; m/z: (ES) $314[\mathrm{M}]^{+}$; found $\mathrm{C}, 34.50 ; \mathrm{H}, 4.55 \%, \mathrm{C}_{9} \mathrm{H}_{14} \mathrm{O}_{2} \mathrm{~S}_{5}$ requires $\mathrm{C}$, $34.37 ; \mathrm{H}, 4.49 \% ;{ }^{293}[\alpha]_{\mathrm{D}}=+61.7\left(\mathrm{c}=1.8, \mathrm{CHCl}_{3}\right)$.

\section{Bis((2'S)-2'-acetoxypropylthio)-1,3-dithiole-2-thione 26.}

Acetic anhydride $(5.0 \mathrm{ml}, 52.9 \mathrm{mmol})$ was added to a solution of thione $25(6.48 \mathrm{~g}, 20.6$ mmol) in pyridine $(70 \mathrm{ml})$ at $0{ }^{\circ} \mathrm{C}$ and then stirred overnight at room temperature. Water (300 ml) was added and the mixture extracted with $\mathrm{CH}_{2} \mathrm{Cl}_{2}(3 \times 100 \mathrm{ml})$. The organic solution was washed consecutively with $0.5 \mathrm{M} \mathrm{HCl}$ solution $(3 \times 100 \mathrm{ml})$ and $\mathrm{H}_{2} \mathrm{O}(100$ $\mathrm{ml})$, dried $\left(\mathrm{MgSO}_{4}\right)$ and evaporated. The residue was purified by flash chromatography $\left(\mathrm{SiO}_{2}\right.$, eluting with cyclohexane:ethyl acetate $\left.4: 1\right)$ to yield the protected thione $26(6.16 \mathrm{~g}$, $75.0 \%)$ as an orange brown oil; $R_{\mathrm{f}}$ (cyclohexane:ethyl acetate 4:1) $0.30 ; \delta_{H}(400 \mathrm{MHz}$, $\left.\mathrm{CDCl}_{3}\right) 4.99(2 \mathrm{H}, \mathrm{m}, 2 \times \mathrm{CHOAc}), 2.99\left(4 \mathrm{H}, \mathrm{d}, \mathrm{J} 5.8 \mathrm{~Hz}, 2 \times \mathrm{CH}_{2} \mathrm{~S}\right), 1.98(6 \mathrm{H}, \mathrm{s}$, $\left.2 \times \mathrm{CH}_{3} \mathrm{CO}\right), 1.29\left(6 \mathrm{H}, \mathrm{d}, \mathrm{J} \quad 6.4 \mathrm{~Hz}, 2 \times \mathrm{CH}_{3}\right) ; \delta_{C}\left(100.6 \mathrm{MHz}, \mathrm{CDCl}_{3}\right) 210.2(\mathrm{C}=\mathrm{S}), 169.9$ $(2 \times C=\mathrm{O}), 136.2(4-, 5-C), 69.0(2 \times C \mathrm{HOAc}), 41.3\left(2 \times \mathrm{CH}_{2} \mathrm{~S}\right), 20.9\left(2 \times \mathrm{CH}_{3} \mathrm{CO}\right), 19.0$ $\left(2 \times \mathrm{CH}_{3}\right)$; $v_{\max }: 2979,2932,1733,1456,1370,1228,1128,1061,1035,955,888,632$, 606, 516, 451, 412; m/z: (ES) $398[\mathrm{M}]^{+}$; found $\mathrm{C}, 39.25 ; \mathrm{H}, 4.58 \%, \mathrm{C}_{13} \mathrm{H}_{18} \mathrm{O}_{4} \mathrm{~S}_{5}$ requires C, 39.17; H, 4.55\%; ${ }^{293}[\alpha]_{\mathrm{D}}=+45\left(\mathrm{c}=1.20, \mathrm{CHCl}_{3}\right)$.

\section{Bis((2'S)-2'-acetoxypropylthio)-1,3-dithiole-2-one 27, (Method A).}

To a solution of the thione $26(5.54 \mathrm{~g}, 13.9 \mathrm{mmol})$ in chloroform $(130 \mathrm{ml})$ was added mercuric acetate $(6.70 \mathrm{~g}, 21.0 \mathrm{mmol})$. After stirring for $2 \mathrm{~h}$, the reaction mixture was filtered and the solid residue washed with chloroform. The combined filtrates were washed with sodium hydrogen carbonate solution and then water, dried over magnesium sulfate, and concentrated in vacuo. The residue was purified by flash chromatography $\left(\mathrm{SiO}_{2}\right.$, eluting with cyclohexane:DCM 3:1) to yield the oxo compound 27 as a brown oil (5.07 g, 95.4\%); R (cyclohexane:DCM 3:1) 0.41; $\delta_{H}\left(400 \mathrm{MHz}, \mathrm{CDCl}_{3}\right) 4.97(2 \mathrm{H}, \mathrm{m}$, $2 \times \mathrm{CHOAc}), 2.94\left(4 \mathrm{H}, \mathrm{d}, \mathrm{J} 5.8 \mathrm{~Hz}, 2 \times \mathrm{CH}_{2} \mathrm{~S}\right), 1.96\left(6 \mathrm{H}, \mathrm{s}, 2 \times \mathrm{CH}_{3} \mathrm{CO}\right), 1.27(6 \mathrm{H}, \mathrm{d}, \mathrm{J} 6.3$ $\left.\mathrm{Hz}, 2 \times \mathrm{CH}_{3}\right) ; \delta_{C}\left(100.6 \mathrm{MHz}, \mathrm{CDCl}_{3}\right) 188.7(\mathrm{C}=\mathrm{O}), 169.9\left(2 \times \mathrm{COCH}_{3}\right), 127.3(4-, 5-C)$, $69.1(2 \times C \mathrm{HOAc}), 41.2\left(2 \times \mathrm{CH}_{2} \mathrm{~S}\right), 20.9\left(2 \times \mathrm{CH}_{3} \mathrm{CO}\right), 18.9\left(2 \times \mathrm{CH}_{3}\right) ; v_{\max }: 2980,2933$, 
1734, 1667, 1613, 1448, 1370, 1229, 1128, 1092, 1037, 955, 883, 739, 632, 607, 551, 461; m/z: (ES) $382[\mathrm{M}]^{+}$; found $\mathrm{C}, 40.81 ; \mathrm{H}, 4.68 \%, \mathrm{C}_{13} \mathrm{H}_{18} \mathrm{O}_{5} \mathrm{~S}_{4}$ requires $\mathrm{C}, 40.82 ; \mathrm{H}$, $4.74 \% ;{ }^{293}[\alpha]_{\mathrm{D}}=+1.0\left(\mathrm{c}=1.80, \mathrm{CHCl}_{3}\right)$.

\section{Tetrakis((2S)-2-acetoxypropylthio)TTF 28, (Method B).}

A mixture of oxo compound $27(3.30 \mathrm{~g}, 8.62 \mathrm{mmol})$ and freshly distilled trimethyl phosphite $(60 \mathrm{ml})$ was heated to reflux for $24 \mathrm{~h}$. The solvent was evaporated to dryness, and the residue was subjected to flash chromatography $\left(\mathrm{SiO}_{2}\right.$, eluting with cyclohexane:ethyl acetate 4:1) to yield the TTF derivative $\mathbf{2 8}$ as an orange oil ( $1.95 \mathrm{~g}$, $30.9 \%) ; \mathrm{R}_{\mathrm{f}}$ (cyclohexane:ethyl acetate $\left.4: 1\right) \quad 0.14 ; \delta_{H}\left(400 \mathrm{MHz}, \mathrm{CDCl}_{3}\right) 5.01(4 \mathrm{H}, \mathrm{m}$, 4×CHOAc), $2.97\left(8 \mathrm{H}, \mathrm{d}, \mathrm{J} 5.7 \mathrm{~Hz}, 4 \times \mathrm{CH}_{2} \mathrm{~S}\right), 2.03\left(12 \mathrm{H}, \mathrm{s}, 4 \times \mathrm{CH}_{3} \mathrm{CO}\right), 1.32(12 \mathrm{H}, \mathrm{d}, \mathrm{J}$ 6.4Hz, $\left.4 \times \mathrm{CH}_{3}\right) ; \delta_{C}\left(100.6 \mathrm{MHz}, \mathrm{CDCl}_{3}\right) 170.1(4 \times C=\mathrm{O}), 127.9$ (4-,4'-,5-,5'-C), 110.6 (2,2'-C), 69.4 (4×CHOAc), $40.9\left(4 \times \mathrm{CH}_{2} \mathrm{~S}\right), 21.1\left(4 \times \mathrm{CH}_{3} \mathrm{CO}\right), 19.0\left(4 \times \mathrm{CH}_{3}\right) ; v_{\max }$ : 2979, 2932, 1733, 1447, 1369, 1227, 1128, 1091, 1034, 954, 890, 856, 772, 632, 606; m/z: ( EI

) $732[\mathrm{M}]^{+}$; found C, 42.69; H, 4.90\%, $\mathrm{C}_{26} \mathrm{H}_{36} \mathrm{O}_{8} \mathrm{~S}_{8}$ requires C, 42.60; H, 4.95\%; ${ }^{293}[\alpha]_{\mathrm{D}}=$ $+60.2\left(\mathrm{c}=1.5, \mathrm{CHCl}_{3}\right)$.

\section{Tetrakis((2S)-2-hydroxylpropylthio)TTF 15.}

An aqueous solution $(60 \mathrm{ml})$ of potassium carbonate $(3.20 \mathrm{~g}, 23.2 \mathrm{mmol})$ was added to a solution of the tetra-acetate $28(1.95 \mathrm{~g}, 2.66 \mathrm{mmol})$ in methanol $(240 \mathrm{ml})$. After stirring overnight, the reaction mixture was concentrated and the solid was collected and washed with water to yield the chiral tetrol 15 as an orange solid $(1.37$ g, $91.2 \%)$; m.p. $91-93^{\circ} \mathrm{C}$; $\mathrm{R}_{\mathrm{f}}$ (ethyl acetate:methanol 10:1) 0.47; $\delta_{H}\left(400 \mathrm{MHz}, \mathrm{CDCl}_{3}\right) 3.83(4 \mathrm{H}, \mathrm{m}, 4 \times \mathrm{CHOH})$, $2.98\left(4 \mathrm{H}, \mathrm{dd}, \mathrm{J} 3.1,13.7 \mathrm{~Hz}, 4 \times \mathrm{CH}_{\alpha} \mathrm{S}\right), 2.95(4 \mathrm{H}, \mathrm{br}, \mathrm{d}, \mathrm{J} 3.0 \mathrm{~Hz}, 4 \times \mathrm{OH}), 2.65(4 \mathrm{H}, \mathrm{dd}, \mathrm{J}$ 8.9, $\left.13.7 \mathrm{~Hz}, 4 \times \mathrm{CH}_{\beta} \mathrm{S}\right), 1.22(12 \mathrm{H}, \mathrm{d}, \mathrm{J}$ 6.3 Hz, 4×CH$) ; \delta_{C}\left(100.6 \mathrm{MHz}, \mathrm{CDCl}_{3}\right) 128.3$ (4-,4'-,5-,5'-C), $110.7\left(2-, 2\right.$ '-C), $66.0(4 \times C \mathrm{HOH}), 45.2\left(4 \times \mathrm{CH}_{2} \mathrm{~S}\right), 21.8\left(4 \times C \mathrm{H}_{3}\right) ; v_{\max }$ : 3320, 2965, 2915, 1455, 1396, 1377, 1294, 1273, 1245, 1124, 1072, 1034, 932, 892, 875, $865,823,770,725,568,465,419,410 ; \mathrm{m} / \mathrm{z}$ : (EI) $564[\mathrm{M}]^{+}$; found $\mathrm{C}, 38.23 ; \mathrm{H}, 5.04 \%$, $\mathrm{C}_{18} \mathrm{H}_{28} \mathrm{O}_{4} \mathrm{~S}_{8}$ requires $\mathrm{C}, 38.27 ; \mathrm{H}, 5.00 \% ;{ }^{293}[\alpha]_{\mathrm{D}}=+212.5\left(\mathrm{c}=0.24, \mathrm{CHCl}_{3}\right)$. 


\section{Bis((2S)-2-acetoxypropylthio)(ethylenedithio)TTF 30, (Method C).}

A mixture of oxo compound 27 (1.70 g, $4.44 \mathrm{mmol})$, thione 29 (3.00 g, $13.4 \mathrm{mmol})$ and freshly distilled trimethyl phosphite $(70 \mathrm{ml})$ was heated to $70{ }^{\circ} \mathrm{C}$ for $30 \mathrm{~h}$. The reaction mixture was cooled to room temperature then filtered and washed with chloroform. The solvent and trimethyl phosphite were removed in vacuo, the residue was subjected to flash chromatography $\left(\mathrm{SiO}_{2}\right.$, eluting with cyclohexane:ethyl acetate $\left.4: 1\right)$ to yield the donor 30 as an orange oil $\left(1.07 \mathrm{~g}, 43.1 \%\right.$ ); $\mathrm{R}_{\mathrm{f}}$ (cyclohexane:ethyl acetate $\left.4: 1\right) \quad 0.26 ; \delta_{H}$ $\left(400 \mathrm{MHz}, \mathrm{CDCl}_{3}\right) 5.01(2 \mathrm{H}, \mathrm{m}, 2 \times \mathrm{CHOAc}), 3.28\left(4 \mathrm{H}, \mathrm{s}, 5^{\prime}-6^{\prime}-\mathrm{H}_{2}\right), 2.97$ (4H, d, J 5.8 $\left.\mathrm{Hz}, 2 \times \mathrm{CH}_{2} \mathrm{~S}\right), 2.03\left(6 \mathrm{H}, \mathrm{s}, 2 \times \mathrm{CH}_{3} \mathrm{CO}\right), 1.32\left(6 \mathrm{H}, \mathrm{d}, \mathrm{J} 6.4 \mathrm{~Hz}, 2 \times \mathrm{CH}_{3}\right) ; \delta_{\mathrm{C}}(100.6 \mathrm{MHz}$, $\left.\mathrm{CDCl}_{3}\right) 170.0(2 \times C=\mathrm{O}), 127.8(4-, 5-C), 113.8$ (3a'-,7a'-C), $112.3 \& 109.7$ (2-,2'-C), 69.3 $(2 \times C \mathrm{HOAc}), 40.8\left(2 \times \mathrm{CH}_{2} \mathrm{~S}\right), 30.0\left(5^{\prime}-, 6^{\prime}-\mathrm{C}\right), 21.0\left(2 \times \mathrm{CH}_{3} \mathrm{CO}\right), 18.9\left(2 \times C \mathrm{H}_{3}\right) ; v_{\max }$ : 2977, 2929, 1732, 1420, 1369, 1228, 1127, 1092, 1035, 955, 889, 857, 772, 632, 606, 395; m/z: ( EI ) $558[\mathrm{M}]^{+}$; found C, 38.72; H, 4.06\%, $\mathrm{C}_{18} \mathrm{H}_{22} \mathrm{O}_{4} \mathrm{~S}_{8}$ requires C, 38.68; H, $3.97 \% ;{ }^{293}[\alpha]_{\mathrm{D}}=+29.3\left(\mathrm{c}=0.74, \mathrm{CHCl}_{3}\right)$.

\section{Bis((2S)-2-hydroxylpropylthio)(ethylenedithio)TTF 16.}

An aqueous solution $(30 \mathrm{ml})$ of potassium carbonate $(1.70 \mathrm{~g}, 12.3 \mathrm{mmol})$ was added to a solution of the di-acetate $30(1.07 \mathrm{~g}, 1.91 \mathrm{mmol})$ in methanol $(240 \mathrm{ml})$ and THF $(20 \mathrm{ml})$. After stirring overnight, the reaction mixture was concentrated and the solid was collected and washed with water to yield the chiral diol 16 as a yellow solid $(855 \mathrm{mg}$, 94.1\%); m.p. $108-110^{\circ} \mathrm{C}$; $\mathrm{R}_{\mathrm{f}}$ (ethyl acetate) $0.41 ; \delta_{H}\left(400 \mathrm{MHz}, \mathrm{CDCl}_{3}\right) 3.79(2 \mathrm{H}, \mathrm{m}$, $2 \times \mathrm{CHOH}), 3.23\left(4 \mathrm{H}, \mathrm{s}, 5^{\prime}-, 6^{\prime}-\mathrm{H}_{2}\right), 2.97\left(2 \mathrm{H}, \mathrm{dd}, \mathrm{J} 3.3,13.8 \mathrm{~Hz}, 2 \times \mathrm{CH}_{\alpha} \mathrm{S}\right), 2.84(2 \mathrm{H}, \mathrm{br}, \mathrm{s}$, $2 \times \mathrm{OH}), 2.62\left(2 \mathrm{H}, \mathrm{dd}, \mathrm{J} 9.0,13.8 \mathrm{~Hz}, 2 \times \mathrm{CH}_{\beta} \mathrm{S}\right), 1.20\left(6 \mathrm{H}, \mathrm{d}, \mathrm{J} 6.3 \mathrm{~Hz}, 2 \times \mathrm{CH}_{3}\right) ; \delta_{C}(100.6$ $\left.\mathrm{MHz}, \mathrm{CDCl}_{3}\right) 128.3$ (4-,5-C), 113.8 (3a'-,7a'-C), 112.3 \& 109.7 (2-,2’-C), 65.9 $(2 \times C \mathrm{HOH}), 45.3\left(2 \times \mathrm{CH}_{2} \mathrm{~S}\right), 30.2\left(5^{\prime}-, 6^{\prime}-C\right), 21.8\left(2 \times \mathrm{CH}_{3}\right) ; v_{\max }: 3306,2965,2916,1451$, $1405,1371,1343,1282,1254,1239,1126,1068,1038,1003,934,915,878,863,812$, 770, 720, 684, 472, 454, 442; m/z: (EI) $474[\mathrm{M}]^{+}$; found C, 35.51; H, 3.84\%, $\mathrm{C}_{14} \mathrm{H}_{18} \mathrm{O}_{2} \mathrm{~S}_{8}$ requires $\mathrm{C}, 35.42 ; \mathrm{H}, 3.82 \% ;{ }^{293}[\alpha]_{\mathrm{D}}=+146\left(\mathrm{c}=0.42, \mathrm{CHCl}_{3}\right)$. 


\section{Synthesis of bis((2R)-2-hydroxylpropylthio)(ethylenedithio)TTF.}

This followed the procedure for the $S$-enantiomer but starting from $(R)-(+)$-propylene oxide to give a final product with optical rotation ${ }^{293}[\alpha]_{\mathrm{D}}=-148\left(\mathrm{c}=0.42, \mathrm{CHCl}_{3}\right)$.

\section{Preparation of 16.Fe2(oxalate)5.}

$\left(\mathrm{NH}_{4}\right)_{3}\left[\mathrm{Fe}\left(\mathrm{C}_{2} \mathrm{O}_{4}\right)_{3}\right] \cdot 3 \mathrm{H}_{2} \mathrm{O}(120 \mathrm{mg})$ and 18-crown-6 (200 mg) in a 1:1 mixture of dichloromethane and acetonitrile $(40 \mathrm{ml})$ was stirred for $6 \mathrm{~h}$. and filtered into both sides of an electrochemical cell which contained donor $\mathbf{1 6}(10 \mathrm{mg})$ in the anode compartment. On applying a current of $1.0 \mu \mathrm{A}$ across the cell, crystals began to grow in the first week and were harvested after 21 days. A large quantity of black plates of $(\mathbf{1 6})_{4}\left[\mathrm{Fe}_{2}\left(\mathrm{C}_{2} \mathrm{O}_{4}\right)_{5}\right]$ were obtained and were found to be suitable for X-ray structure determination.

\section{Preparation of complex of 16 withTCNQ-F 4 .}

TCNQ-F 4 : A solution of TCNQ- $\mathrm{F}_{4}(7 \mathrm{mg})$ in acetonitrile $(3 \mathrm{ml})$ was gently layered over a solution of diol $16(12 \mathrm{mg})$ in chloroform $(3 \mathrm{ml})$ and left to slowly evaporate giving black crystals of a 1:1 complex whose composition was determined by X-ray crystallography.

\section{4,5-Bis(((4'R)-2',2'-dimethyl-1',3'-dioxolan-4'-yl)methylthio)-1,3-dithiole-2-thione} 31.

A solution of disodium dithiolate $\mathbf{2 4}$ in dry methanol $(10 \mathrm{ml})$, prepared in situ from 4,5bis(benzoylthio)-1,3-dithiol-2-thione $(410 \mathrm{mg}, 1.0 \mathrm{mmol})$ and sodium methoxide (0.48

$\mathrm{ml}$, solution $25 \% \mathrm{wt}, 2.0 \mathrm{mmol}$ ) under a nitrogen atmosphere, ${ }^{25}$ was treated with a freshly prepared sample of the triflate of (S)-1,2-isopropylidene glycerol ${ }^{33}(528 \mathrm{mg}, 2.0 \mathrm{mmol})$ at room temperature. After $5 \mathrm{~min}$ an orange precipitate formed, which was collected, washed with methanol and dried to yield $\mathbf{3 1}$ as a yellow solid (390 mg, 90\%); m.p. 124 ${ }^{\circ} \mathrm{C} ; \mathrm{R}_{\mathrm{f}}$ (cyclohexane:ethyl acetate 5:1) 0.32; $\delta_{\mathrm{H}}\left(400 \mathrm{MHz}, \mathrm{CDCl}_{3}\right) 4.26(2 \mathrm{H}$, quin, J 6.0 $\mathrm{Hz}, 2$ x 4'-H), $4.11\left(2 \mathrm{H}\right.$, dd, J 6.2, $8.4 \mathrm{~Hz}, 2$ x 5'- $\left.H_{\alpha}\right), 3.74(2 \mathrm{H}$, dd, J 5.4, $8.4 \mathrm{~Hz}, 2$ x 5'-

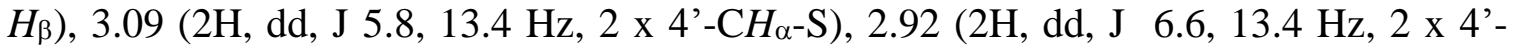
$\left.\mathrm{CH}_{\beta}-\mathrm{S}\right), 1.40\left(6 \mathrm{H}, \mathrm{s}, 2 \mathrm{x}-\mathrm{CH}_{3}\right), 1.32\left(6 \mathrm{H}, \mathrm{s}, 2 \mathrm{x}-\mathrm{CH}_{3}\right) ; \delta_{\mathrm{C}}\left(100 \mathrm{MHz}, \mathrm{CDCl}_{3}\right) 210.0(2-$ 
C), 136.1 (4-, 5- C), 110.1 (2 x 2'-C), 74.5 (2 x 4'-C), 68.4 (2 × 5'-C), 39.6 (2 x 4'- $C \mathrm{H}_{2-}$ $\mathrm{S}), 26.9\left(2 \mathrm{x}-\mathrm{CH}_{3}\right), 25.3\left(2 \mathrm{x}-\mathrm{CH}_{3}\right)$; $v_{\max }$ : 2990, 2876, 1370, 1214, 1051, 1036, 894, 864, 816, 421; m/z: (ESI) $449[\mathrm{M}+\mathrm{Na}]^{+}, 413,301 ; H R M S$ (ESI) found: 449.0008, $\mathrm{C}_{15} \mathrm{H}_{22} \mathrm{O}_{4} \mathrm{~S}_{5}$ $+\mathrm{Na}$ requires $449.0014 ;{ }^{293}[\alpha]_{\mathrm{D}}=-41.6(c=0.24, \mathrm{THF})$.

\section{4,5-Bis(((4'R)-2',2'-dimethyl-1',3'-dioxolan-4'-yl)methylthio)-1,3-dithiol-2-one 32.}

From 31 (0.39 g, $9.1 \mathrm{mmol})$ using Method A gave $32(0.35 \mathrm{~g}, 93 \%)$ as a yellow oil; $\mathrm{R}_{\mathrm{f}}$ (cyclohexane:ethyl acetate 5:1) 0.42; $\delta_{\mathrm{H}}\left(400 \mathrm{MHz} \mathrm{CDCl}_{3}\right) 4.22(2 \mathrm{H}$, quin, J $6.0 \mathrm{~Hz}, 2 \mathrm{x}$ 4'-H), 4.07 (2H, dd, J 6.2, 8.4 Hz, 2 x 5'- $\left.H_{\alpha}\right), 3.72\left(2 \mathrm{H}, \mathrm{dd}, \mathrm{J} 5.4,8.4 \mathrm{~Hz}, 2\right.$ x 5'- $\left.H_{\beta}\right)$,

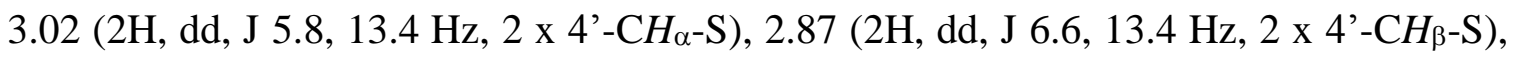
$1.36\left(6 \mathrm{H}, \mathrm{s}, 2 \times \mathrm{CH}_{3}\right), 1.28\left(6 \mathrm{H}, \mathrm{s}, 2 \times \mathrm{CH}_{3}\right) ; \delta_{\mathrm{C}}\left(100 \mathrm{MHz} \mathrm{CDCl}_{3}\right) 188.6(2-\mathrm{C}), 127.1$ (4-, 5- C), 109.8 ( 2 x 2'-C), 74.4 (2 x 4'-C), 68.3 (2 x 5'-C) 39.3 (2 x 4'-CH $\left.\mathrm{H}_{2}-\mathrm{S}\right), 26.8$ (2 $\left.\mathrm{x}-\mathrm{CH}_{3}\right), 25.2\left(2 \mathrm{x}-\mathrm{CH}_{3}\right) ; v_{\max }$ 2985, 1668, 1370, 1213, 1149, 1057, 884, 755; m/z: (ESI) $428\left[\mathrm{M}+\mathrm{NH}_{4}\right]^{+}, 386,353,294,217,186 ; H R M S$ (ESI) found: 428.0686; $\left[\mathrm{C}_{15} \mathrm{H}_{22} \mathrm{O}_{5} \mathrm{~S}_{4}+\right.$ $\left.\mathrm{NH}_{4}\right]$ requires $428.0688\left[\mathrm{M}+\mathrm{NH}_{4}\right]^{+}$; found $\mathrm{C}, 35.51 ; \mathrm{H}, 3.84 \%, \mathrm{C}_{14} \mathrm{H}_{18} \mathrm{O}_{2} \mathrm{~S}_{8}$ requires $\mathrm{C}$, $35.42 ; \mathrm{H}, 3.82 \% ;{ }^{293}[\alpha]_{\mathrm{D}}=+28.5(c=0.28, \mathrm{THF})$.

\section{Tetrakis(((4'R)-2',2'-dimethyl-1',3'-dioxolan-4'-yl)methylthio)TTF 33.}

A suspension of compound $32(348 \mathrm{mg}, 8.5 \mathrm{mmol})$ in freshly distilled triethyl phosphite $(7 \mathrm{ml})$ was heated to $90{ }^{\circ} \mathrm{C}$ under nitrogen for $6 \mathrm{~h}$. The resulting orange precipitate was filtered off, washed with n-hexane and dried to afford 33. The triethyl phosphite was removed from the filtrate by Kugelrohr distillation, and residue was washed with hexane, filtered and dried to yield further donor 33, an orange solid, total yield (169 mg. 51\%); m.p. $146-147^{\circ} \mathrm{C} ; \mathrm{R}_{\mathrm{f}}$ (cyclohexane:ethyl acetate 5:1) 0.22; $\delta_{\mathrm{H}}\left(400 \mathrm{MHz}, \mathrm{CDCl}_{3}\right) 4.28(4$

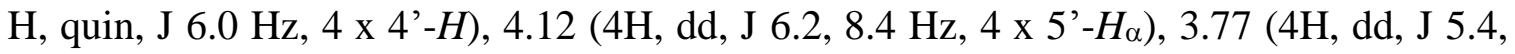

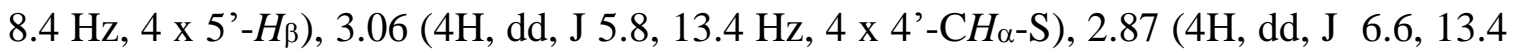
$\mathrm{Hz}, 4 \times$ x 4'-CH$\beta-\mathrm{S}), 1.41\left(12 \mathrm{H}, \mathrm{s}, 4 \times \mathrm{CH}_{3}\right), 1.32\left(12 \mathrm{H}, \mathrm{s}, 4 \times \mathrm{CH}_{3}\right) ; \delta_{\mathrm{C}}(100 \mathrm{MHz}$, $\left.\mathrm{CDCl}_{3}\right) 127.7$ (4 x sp $\left.{ }^{2}-C\right), 110.2$ (2 x $s p^{2}-C$ ), 109.9 (4 x 2'-C), 74.8 (4 x 4'-C), 68.5 (4 x 5'-C) 39.1 (4 x 4'-CH $2-\mathrm{S}), 26.9\left(4 \mathrm{x}-\mathrm{CH}_{3}\right), 25.4\left(4 \mathrm{x}-\mathrm{CH}_{3}\right) ; v_{\max }: 2985,2938,2883$, 
1369, 1224, 1202, 1150, 1052, 1020, 864, 841, 820, 770, 511, $408 \mathrm{~cm}^{-1} ; \mathrm{m} / \mathrm{z}:$ (ESI) 806 $\left[\mathrm{M}+\mathrm{NH}_{4}\right]^{+}, 613,437,351,312,219,197$; HRMS: (ESI) found: 806.1142, $\left[\mathrm{C}_{30} \mathrm{H}_{44} \mathrm{O}_{8} \mathrm{~S}_{8}+\right.$ $\mathrm{NH}_{4}$ ] requires: 806.1140; found $\mathrm{C}, 45.77 ; \mathrm{H}, 5.53 \%, \mathrm{C}_{30} \mathrm{H}_{44} \mathrm{O}_{8} \mathrm{~S}_{8}$ requires $\mathrm{C}, 45.66 ; \mathrm{H}$, $5.62 \% ;{ }^{293}[\alpha]_{\mathrm{D}}=+77.5 \quad(c=0.40, \mathrm{THF})$.

\section{Tetrakis((2'R)-2'-,3'-dihydroxypropyl-1'-thio)TTF 17, (Method D).}

An aqueous solution of $\mathrm{HCl}(0.5 \mathrm{M}, 7 \mathrm{ml})$ was added to a solution of tetra-ketal $\mathbf{3 3}$ (158 $\mathrm{mg}, 0.2 \mathrm{mmol})$ in methanol $(10 \mathrm{ml})$ and tetrahydrofuran $(3 \mathrm{ml})$ which was stirred under nitrogen for $12 \mathrm{~h}$. Evaporation and drying in vacuo at room temperature afforded the octol 17 (122 mg, $97 \%)$ as a brown solid; m.p. $164-166{ }^{\circ} \mathrm{C} ; \delta_{\mathrm{H}}\left(400 \mathrm{MHz},\left(\mathrm{CD}_{3}\right)_{2} \mathrm{SO}\right)$ $4.30(8 \mathrm{H}, \mathrm{br}, 8$ x OH$), 3.56(4 \mathrm{H}, \mathrm{m}, 4$ x 2'- $\mathrm{H}), 3.45\left(8 \mathrm{H}, \mathrm{m}, 4\right.$ x 3'- $\left.\mathrm{H}_{2}\right), 2.93(4 \mathrm{H}, \mathrm{m}, 4 \mathrm{x}$ 1'- $\left.H_{\alpha}\right), 2.79\left(4 \mathrm{H}, \mathrm{m}, 4\right.$ x 1'- $\left.H_{\beta}\right)$; $\delta_{\mathrm{C}}\left(100 \mathrm{MHz},\left(\mathrm{CD}_{3}\right)_{2} \mathrm{SO}\right) 126.9$ (4-, 4'-, 5-, 5'-C), 109.4 (2-, 2'-C), $70.5(4 \mathrm{x}-\mathrm{CH}(\mathrm{OH})), 64.2\left(4 \mathrm{x}-\mathrm{CH}_{2} \mathrm{OH}\right), 39.7\left(4 \mathrm{x}-\mathrm{CH}_{2} \mathrm{~S}\right) ; v_{\max } 3243 \mathrm{br}$, 2916, 1395, 1229, 1063, 1018, 878, $770 \mathrm{~cm}^{-1} ; \mathrm{m} / z$ : (ESI) 627 [M - H]; HRMS (ESI) found: 626.9467, $\left[\mathrm{C}_{18} \mathrm{H}_{28} \mathrm{O}_{8} \mathrm{~S}_{8}-\mathrm{H}\right]$ requires 626.9468; found $\mathrm{C}, 34.30 ; \mathrm{H}, 4.38 \%$, $\mathrm{C}_{18} \mathrm{H}_{28} \mathrm{O}_{8} \mathrm{~S}_{8}$ requires $\mathrm{C}, 34.37 ; \mathrm{H}, 4.49 \% ;{ }^{293}[\alpha]_{\mathrm{D}}=-116.6(c=0.24$, THF $)$.

\section{Bis(((4'R)-2',2'-dimethyl-1',3'-dioxan-4'-yl)methylthio)(ethylenedithio)TTF 34.}

Reaction of $29(0.35 \mathrm{~g}, 0.85 \mathrm{mmol})$ and $32(0.29 \mathrm{~g}, 1.27 \mathrm{mmol})$ in triethyl phosphite (7 $\mathrm{ml}$ ) at $90{ }^{\circ} \mathrm{C}$ using Method $\mathbf{B}$ gave the protected donor 34 (301 mg. 60\%) as a red brown solid; m.p. 69-71 ${ }^{\circ} \mathrm{C} ; \mathrm{R}_{\mathrm{f}}$ (cyclohexane:ethyl acetate 5:1) 0.38; $\delta_{\mathrm{H}}\left(400 \mathrm{MHz}, \mathrm{CDCl}_{3}\right) 4.22$ ( $2 \mathrm{H}$, quin, J $6.0 \mathrm{~Hz}, 2$ x 4'-H), $4.07\left(2 \mathrm{H}, \mathrm{dd}, \mathrm{J} 6.2,8.4 \mathrm{~Hz}, 2\right.$ x 5'- $\left.H_{\alpha}\right), 3.72(2 \mathrm{H}, \mathrm{dd}, \mathrm{J}$ 5.4, $8.4 \mathrm{~Hz}, 2$ x 5'- $\left.\mathrm{H}_{\beta}\right), 3.20\left(4 \mathrm{H}, \mathrm{s},\left(\mathrm{SCH}_{2}\right)_{2}\right), 2.99$ (2H, dd, J 5.8, $13.4 \mathrm{~Hz}, 2$ x 4'-CH $\alpha^{-}$

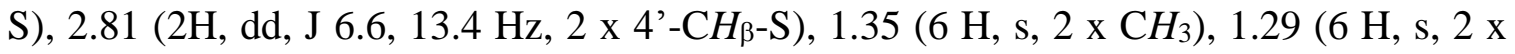
$\left.\mathrm{CH}_{3}\right) ; \delta_{\mathrm{C}}\left(100 \mathrm{MHz}, \mathrm{CDCl}_{3}\right) 127.6\left(2 \times s p^{2} \mathrm{C}\right), 113.8\left(2 \times s p^{2}-\mathrm{C}\right), 112.2 \& 110.1\left(2 \times s p^{2}-\right.$ $\mathrm{C}$ (central)), 109.8 ( 2- \& 2'-C), 74.4 (2 x 4'-C), 68.3 ( 2 x 5'-C) 39.3 ( 2 x 4'- $\left.\mathrm{CH}_{2}-\mathrm{S}\right), 30.1$ ( $\left.\left(\mathrm{SCH}_{2}\right)_{2}\right), 26.8\left(2 \mathrm{x}-\mathrm{CH}_{3}\right), 25.2\left(2 \mathrm{x}-\mathrm{CH}_{3}\right) ; v_{\max }: 2982,2925,2873,1369,1256,1212$, 
1149, 1057, 842, 772; m/z: (ESI) $586\left[\mathrm{M}^{+}\right]$, 536, 502, 462, 391, 279, 217, 186; HRMS: (ESI) found: $586.9675, \mathrm{C}_{15} \mathrm{H}_{26} \mathrm{O}_{4} \mathrm{~S}_{8}+\mathrm{H}$ requires 586.9670 found $\mathrm{C}, 41.03 ; \mathrm{H}, 4.54 \%$, $\mathrm{C}_{15} \mathrm{H}_{26} \mathrm{O}_{4} \mathrm{~S}_{8}$ requires $\mathrm{C}, 40.93 ; \mathrm{H}, 4.46 \% ; \mathrm{N}, 3.20 \% ;{ }^{293}[\alpha]_{\mathrm{D}}=+28.0(c=0.25$, THF).

\section{Bis((2'R)-2',-3'-dihydroxypropyl-1'-thio)(ethylenedithio) TTF 18.}

From 34 (0.14 g, $0.24 \mathrm{mmol})$ using Method D, afforded the tetrol 18 (114 mg, $95 \%)$ as a brown solid; m.p. $94{ }^{\circ} \mathrm{C} ; \quad \delta_{\mathrm{H}}\left(400 \mathrm{MHz},\left(\mathrm{CD}_{3}\right)_{2} \mathrm{SO}\right) 4.80(4 \mathrm{H}$, br $4 \mathrm{x}-\mathrm{OH}), 3.50(2 \mathrm{H}, \mathrm{m}$ , 2 x CH-OH), 3.30 (4 H, m, 2 x - $\left.\mathrm{CH}_{2} \mathrm{OH}\right), 2.91(2 \mathrm{H}, \mathrm{dd}, \mathrm{J}$ 6.2, 8.4 Hz, 2 x 1'-Ho), 2.75 $\left(2 \mathrm{H}, \mathrm{dd}, \mathrm{J} 5.4,8.4 \mathrm{~Hz}, 2\right.$ x 1'- $\left.H_{\beta}\right), 2.41\left(4 \mathrm{H}, \mathrm{s},\left(\mathrm{SCH}_{2}\right)_{2}\right) ; \delta_{\mathrm{C}}\left(100 \mathrm{MHz},\left(\mathrm{CD}_{3}\right)_{2} \mathrm{SO}\right) 127.0$ $\left(2 \times s p^{2} C\right), 112.8\left(2 \times s p^{2} C\right), 113.2 \& 110.1\left(2 \times s p^{2}-\mathrm{C}\right.$ (central)), $70.5(2 \mathrm{x}-C \mathrm{H}(\mathrm{OH}))$, $64.2\left(2 \mathrm{x}-\mathrm{CH}_{2} \mathrm{OH}\right), 39.7\left(2 \mathrm{x}-\mathrm{CH}_{2} \mathrm{~S}\right), 29.5\left(\left(\mathrm{SCH}_{2}\right)_{2}\right) ;$ vmax: 3244 br, 2919, 1395, 1290, 1259, 1182, 1109, 1061, 1016, 877, 767; m/z: (ESI) found: 505 [M - H], 503, 501, 491, 455, 364; HRMS (ESI) found: 504.8898, $\left[\mathrm{C}_{14} \mathrm{H}_{18} \mathrm{O}_{4} \mathrm{~S}_{8}-\mathrm{H}\right]$ requires: 504.8889; found $\mathrm{C}$, $33.16 ; \mathrm{H}, 3.54 \%, \mathrm{C}_{14} \mathrm{H}_{18} \mathrm{O}_{4} \mathrm{~S}_{8}$ requires $\mathrm{C}, 33.18 ; \mathrm{H}, 3.58 \% ;{ }^{293}[\alpha]_{\mathrm{D}}=-390(c=0.40$, $\mathrm{MeOH})$.

\section{vic-Bis(((4R)-2,2-dimethyl-1,3-dioxolan-4-yl)methylthio)-vic-bis((2'R)-2'-} acetoxy)propylthio)TTF 35.

From oxo compound $32(1.10 \mathrm{~g}, 3.0 \mathrm{mml})$ and $R, R-26(1.28 \mathrm{~g}, 3.0 \mathrm{mmol})$ and triethyl phosphite $(10 \mathrm{ml})$ following Method $\mathrm{C}$, but filtering off donor $\mathbf{3 3}$ at the end of the reaction, to yield the donor 35 as a brown oil (686 mg, $30 \%$ ); $\mathrm{R}_{\mathrm{f}}$ (cyclohexane:ethyl acetate 3:1) 0.44; $\delta_{\mathrm{H}}\left(400 \mathrm{MHz} \mathrm{CDCl}_{3}\right): 4.97\left(2 \mathrm{H}, \mathrm{m}, 2 \times 2^{\prime}-H\right), 4.23(2 \mathrm{H}$, quin, J 6.0 Hz, 2 x 4-H), $4.10(2 \mathrm{H}, \mathrm{dd}, \mathrm{J} 6.2,8.4 \mathrm{~Hz}, 2$ x 5-H $), 3.72(2 \mathrm{H}, \mathrm{dd}, \mathrm{J} 5.4,8.4 \mathrm{~Hz}, 2$ x 5$\left.H_{\beta}\right), 3.15\left(2 \mathrm{H}, \mathrm{dd}, \mathrm{J} 5.8,13.4 \mathrm{~Hz}, 2\right.$ x 4-CHa-S), $2.93\left(4 \mathrm{H}, \mathrm{d}, \mathrm{J} 5.8 \mathrm{~Hz}, 2 \times 1\right.$ ' $\left.-H_{2}\right), 2.80$

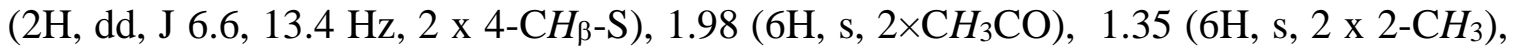
$1.29\left(6 \mathrm{H}, \mathrm{s}, 2 \times 2-\mathrm{CH}_{3}\right), 1.28\left(6 \mathrm{H}, \mathrm{d}, \mathrm{J} 6.4 \mathrm{~Hz}, 2 \times 3\right.$ ' $\left.-\mathrm{CH}_{3}\right) ; \delta_{\mathrm{C}}\left(100 \mathrm{MHz}, \mathrm{CDCl}_{3}\right) 170.0$ $(2 \times C=\mathrm{O}), 127.9\left(2 \times s p^{2}-C\right), 127.6\left(2 \times s p^{2}-C\right), 110.9 \& 110.5\left(2 \times s p^{2}-C(\right.$ central $\left.)\right), 109.8$ ( 2 x 2-C), $74.4(2 \times 4-C), 69.3\left(2 \times 2^{\prime} C\right), 68.3(2 \times 5-C), 40.9(2 \times 1 '-C), 38.9(2 \times 4-$ 
$\left.\mathrm{CH}_{2}-\mathrm{S}\right), 26.8$ (2 x 2-CH 3$), 25.4\left(2 \times 2-\mathrm{CH}_{3}\right) 21.0\left(2 \times \mathrm{CH}_{3} \mathrm{CO}\right), 19.0\left(2 \times 3{ }^{\prime}-\mathrm{CH}_{3}\right) ; \quad v_{\max }$ : 3324, 2927, 2850, 1737, 1625, 1517, 1370, 1310, 1229, 1088, 1055, 892, 642, 393; HRMS (ESI) found: 778.0827, $\left[\mathrm{C}_{28} \mathrm{H}_{40} \mathrm{O}_{8} \mathrm{~S}_{8}+\mathrm{NH}_{4}\right]^{+}$requires: $778.0827 ;{ }^{293}[\alpha]_{\mathrm{D}}=+11.6$ $(c=0.345, \mathrm{THF})$.

\section{vic-Bis(((4R)-2,2-dimethyl-1,3-dioxolan-4-yl)methylthio)-vic-bis((2'R)-2'-}

\section{hydroxypropylthio)-TTF 36.}

An aqueous solution $(2.5 \mathrm{ml})$ of potassium carbonate $(142 \mathrm{mg}, 1.0 \mathrm{mmol})$ was added to a solution of 35 (100 mg, $0.13 \mathrm{mmol})$ in methanol $(10 \mathrm{ml})$ and tetrahydrofuran $(1.5 \mathrm{ml})$ which was stirred under nitrogen for $12 \mathrm{~h}$. The solvents were evaporated under vacuum, and the orange solid collected, washed with water and dried to yield the chiral diol 29 as a light orange powder (84 mg, 95\%); m.p. $92-93{ }^{\circ} \mathrm{C}$; $\mathrm{R}_{\mathrm{f}}$ (cyclohexane:ethyl acetate 1:1) 0.47; $\delta_{H}\left(400 \mathrm{MHz}, \mathrm{CD}_{3} \mathrm{OD}\right): 4.26\left(2 \mathrm{H}, \mathrm{m}, 2\right.$ x 4-H), $4.14\left(2 \mathrm{H}, \mathrm{t}, \mathrm{J} 6.6 \mathrm{~Hz}, 2\right.$ x 5- $\left.H_{\alpha}\right)$, $3.88\left(2 \mathrm{H}, \mathrm{m}, 2\right.$ x 2'- $\left.H_{\beta}\right), 3.76\left(2 \mathrm{H}, \mathrm{t}, \mathrm{J} 6.6 \mathrm{~Hz}, 2\right.$ x 5-H $\left.\mathrm{H}_{\beta}\right), \quad 3.07(2 \mathrm{H}, \mathrm{dd}, \mathrm{J} 5.8,13.4 \mathrm{~Hz})$ and $2.95(6 \mathrm{H}, \mathrm{m}), 4$ x $\left.-\mathrm{CH}_{2} \mathrm{~S}\right), 1.39\left(6 \mathrm{H}, \mathrm{s}, 2 \mathrm{x} 2-\mathrm{CH}_{3}\right), 1.31\left(6 \mathrm{H}, \mathrm{s}, 2 \mathrm{x} 2-\mathrm{CH}_{3}\right), 1.25(6 \mathrm{H}$, d, J $6.4 \mathrm{~Hz}, 2$ x $\left.\mathrm{CHCH}_{3}\right) ; \delta_{C}\left(100 \mathrm{MHz}, \mathrm{CD}_{3} \mathrm{OD}\right)$ : 129.3 (4 x sp $\left.{ }^{2}-C\right), 110.9$ (2 x sp ${ }^{2}-$ $C($ central)), 109.8 ( 2 x 2-C), 76.4 (2 x 4-C), 69.5 (2 x 2’-C), 67.8 (2 x 5-C), 45.3 (2 x 1'-

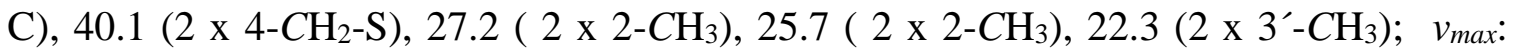
$3355,2984,1370,1243,1226,1203,1053,864,770 \mathrm{~cm}^{-1}$; found $42.49 ; \mathrm{H}, 5.36 \%$, $\mathrm{C}_{24} \mathrm{H}_{36} \mathrm{O}_{6} \mathrm{~S}_{8}$ requires $\mathrm{C}, 42.57 ; \mathrm{H}, 5.36 \% ;{ }^{293}[\alpha]_{\mathrm{D}}=+266$ (c = 0.015, methanol).

\section{vic-Bis((2R)-2,3-dihydroxypropylthio)-vic-bis((2'R)-2'-hydroxypropylthio)-TTF 19.}

Donor 36 (100 mg, $0.14 \mathrm{mmol}$ ) was hydrolysed following Method D to yield the chiral hexol 19 (85 mg, 96\%) as a deep orange solid, m.p. 125-126 ${ }^{\circ} \mathrm{C} ; \mathrm{R}_{\mathrm{f}}$ (ethyl acetate:methanol 9:1) 0.28; $\delta_{H}\left(\mathrm{CD}_{3} \mathrm{OD}\right): 3.87(2 \mathrm{H}, \mathrm{m}, 2 \times 2-H), 3.73\left(2 \mathrm{H}, \mathrm{m}, 2 \times 2^{\prime}-H\right)$, $3.59\left(4 \mathrm{H}, \mathrm{m}, 2 \mathrm{x} 3-\mathrm{H}_{2}\right), 3.02(2 \mathrm{H}, \mathrm{m})$ and $2.90(6 \mathrm{H}, \mathrm{m})\left(2 \times 1-\mathrm{H}_{2}, 2 \times 1\right.$ ' $\left.-\mathrm{H}_{2}\right), 1.26(6 \mathrm{H}, \mathrm{d}$, J $\left.6.3 \mathrm{~Hz}, 2 \times-\mathrm{CH}_{3}\right) ; \delta_{C}\left(\mathrm{CD}_{3} \mathrm{OD}\right) 129.5\left(2 \mathrm{x} \mathrm{sp}^{2}-C\right), 129.4\left(2 \mathrm{x} \mathrm{sp}^{2}-C\right), 110.3 \& 109.7(2 \mathrm{x}$ $\mathrm{sp}^{2}-C$ (central)), $72.3(2 \times 2-C), 67.8\left(2 \times 2^{\prime}-C\right), 65.8(2 \times 3-C), 44.3\left(2 \times 1^{\prime}-C\right), 40.1(2 \times$ 1-C), 22.3 (2 x 3’-C); $v_{\max }: 3293,2966,2918,1395,1372,1066,1033,885,771$; found 
$\mathrm{C}, 36.13 ; \mathrm{H}, 4.68 \%, \mathrm{C}_{18} \mathrm{H}_{28} \mathrm{O}_{6} \mathrm{~S}_{8}$ requires $\mathrm{C}, 36.22 ; \mathrm{H}, 4.73 \% ;{ }^{293}[\alpha]_{\mathrm{D}}=-40.1(\mathrm{c}=0.20$, THF).

\section{S-5-(1'-tert-Butyldiphenylsilyloxyprop-2'-yl)-1,3-dithiolo[4,5-c]pyrrolo-2-thione 39.}

A mixture of (2S)-1-(tert-butyldiphenylsilyloxy)propyl-2-amine $37^{29}$ (3.51 g, 11.2 mmol), bis(dibromomethyl)-1,3-dithiol-2-thione ${ }^{28} \quad(3.50 \mathrm{~g}, 10.9 \mathrm{mmol})$, sodium carbonate $(3.50 \mathrm{~g}, 33.0 \mathrm{mmol})$ and tetrabutylammonium iodide $(1.00 \mathrm{~g}, 2.7 \mathrm{mmol})$ in THF (120ml) was refluxed under nitrogen overnight. After removal of solvent, the residue containing thione 38 was redissolved in chloroform $(200 \mathrm{ml})$. After cooling to $-15{ }^{\circ} \mathrm{C}$, a solution of DDQ (3.20 g, $14.1 \mathrm{mmol})$ in benzene $(80 \mathrm{ml})$ was added dropwise and resulted in the formation of a dark suspension. The mixture was stirred for another $2 \mathrm{~h}$ and then neutralised with $1 \mathrm{M}$ sodium carbonate solution. The mixture was extracted with DCM, and the combined organic solution was washed with $1 \mathrm{M}$ sodium carbonate solution and water before drying over magnesium sulfate. The filtrate was evaporated at $30{ }^{\circ} \mathrm{C}$ in vacuo, and the residue was purified by flash chromatography $\left(\mathrm{SiO}_{2}\right.$, eluting with cyclohexane:ethyl acetate 10:1) to yield the thione 39 as a yellow solid (2.86 g, 52.6\%); m.p. $114-116{ }^{\circ} \mathrm{C}$ (dec.); $\mathrm{R}_{\mathrm{f}}$ (cyclohexane:ethyl acetate $\left.10: 1\right) \quad 0.28 ; \delta_{H}\left(400 \mathrm{MHz}, \mathrm{CDCl}_{3}\right)$ $7.58\left(2 \mathrm{H}, \mathrm{m}, \mathrm{Ar}-\mathrm{H}_{2}\right), 7.52$ (2H, m, Ar- $\left.\mathrm{H}_{2}\right), 7.40$ (6H, m, Ar- $\left.H_{6}\right), 6.77$ (2H, s, 4-,6-H), 4.29 $\left(1 \mathrm{H}, \mathrm{m}, 2^{\prime}-H\right), 3.87\left(1 \mathrm{H}, \mathrm{dd}, \mathrm{J} 10.8,4.1 \mathrm{~Hz}, 1\right.$ '- $\left.H_{\alpha}\right), 3.74\left(1 \mathrm{H}, \mathrm{dd}, \mathrm{J} 10.8,6.7 \mathrm{~Hz}, 1^{\prime}-H_{\beta}\right)$, $1.52\left(3 \mathrm{H}, \mathrm{d}, \mathrm{J} 6.9 \mathrm{~Hz}, \mathrm{CH}_{3}\right), 1.08\left(9 \mathrm{H}, \mathrm{s}, \mathrm{C}\left(\mathrm{CH}_{3}\right)_{3}\right) ; \delta_{C}\left(100.6 \mathrm{MHz}, \mathrm{CDCl}_{3}\right) 219.0$ (2-C), 135.5, 135.4, 133.5, 129.6, 127.6 (Ar- $\left.C_{12}\right), 122.0$ (3a-,6a-C), $110.5(4-, 6-C), 67.8$ $\left(\mathrm{CH}_{2} \mathrm{OSi}\right), 58.3(\mathrm{CHN}), 26.4\left(\mathrm{C}_{\left.\left(\mathrm{CH}_{3}\right)_{3}\right),} 18.8\left(\mathrm{C}\left(\mathrm{CH}_{3}\right)_{3}\right), 16.9\left(\mathrm{CH}_{3}\right) ; v_{\text {max }}: 2930,2855\right.$, 1485, 1471, 1427, 1389, 1302, 1138, 1102, 1074, 1051, 1019, 985, 872, 813, 760, 743, 701, 614, 600, 492; m/z: (EI) $469[\mathrm{M}]^{+}$; found $\mathrm{C}, 61.42 ; \mathrm{H}, 5.81 ; \mathrm{N}, 2.89 \%, \mathrm{C}_{24} \mathrm{H}_{27} \mathrm{NS}_{3} \mathrm{Si}$ requires $\mathrm{C}, 61.36 ; \mathrm{H}, 5.79 ; \mathrm{N}, 2.98 \% ;{ }^{293}[\alpha]_{\mathrm{D}}=-11.7(\mathrm{c}=0.06, \mathrm{THF})$.

\section{$S, S$-Bis(N-1''-tert-butyldiphenylsilyloxyprop-2''-yl)pyrrolo[3,4-d])tetrathiafulvalene 40}

Reaction of 39 (2.84 g, $6.05 \mathrm{mmol})$ in trimethyl phosphite $(70 \mathrm{ml})$ using Method B and refluxing for $51 \mathrm{~h}$ gave the donor $\mathbf{4 0}$ as a yellow solid $(0.85 \mathrm{mg}, 32.1 \%)$; m.p. $86-88{ }^{\circ} \mathrm{C}$ (dec.); $\mathrm{R}_{\mathrm{f}}$ (cyclohexane:ethyl acetate 10:1) 0.39; $\delta_{H}\left(400 \mathrm{MHz}, \mathrm{CDCl}_{3}\right) 7.45(4 \mathrm{H}, \mathrm{m}, \mathrm{Ar}-$ 
$\left.H_{4}\right), 7.39\left(4 \mathrm{H}, \mathrm{m}, \mathrm{Ar}-H_{4}\right), 7.30\left(12 \mathrm{H}, \mathrm{m}, \mathrm{Ar}-H_{12}\right), 6.40\left(4 \mathrm{H}, \mathrm{s}, 4-, 6-4^{\prime}-, 6\right.$ '- $\left.H\right), 3.99$ (2H, m, 2×2' '-H), $3.63\left(2 \mathrm{H}, \mathrm{dd}, \mathrm{J} 10.2,4.5 \mathrm{~Hz}, 2 \times 1\right.$ ' $\left.-H_{\alpha}\right), 3.55(2 \mathrm{H}, \mathrm{dd}, \mathrm{J} 10.2,6.4 \mathrm{~Hz}, 2 \times 1$ '”$\left.H_{\beta}\right), 1.35\left(6 \mathrm{H}, \mathrm{d}, \mathrm{J} 6.8 \mathrm{~Hz}, 2 \times \mathrm{CH}_{3}\right), 0.94\left(18 \mathrm{H}, \mathrm{s}, 2 \times \mathrm{C}\left(\mathrm{CH}_{3}\right)_{3}\right) ; \delta_{C}\left(100.6 \mathrm{MHz}, \mathrm{CDCl}_{3}\right)$ 135.6, 135.5, 133.0, 132.7, 129.9, 129.7, 127.8 (Ar-C20), 120.0 (2-,2'-C), 118.6 (3a-,3a',6a-,6a'-C), 110.9 (4-,4'-,6-,6'-C), $68.3\left(2 \times 1{ }^{\prime \prime}-C\right), 57.9\left(2 \times 2\right.$ '’-C), $26.7\left(2 \times \mathrm{C}\left(C_{3}\right)_{3}\right)$, $19.1\left(2 \times C\left(\mathrm{CH}_{3}\right)_{3}\right), 17.2\left(2 \times 3{ }^{\prime}{ }^{-}-C\right)$; $v_{\max }$ : 2930, 2856, 1488, 1471, 1427, 1368, 1301, 1104, 1071, 1021, 824, 759, 740, 699, 609, 501, 485; m/z: (EI) $874[\mathrm{M}]^{+}$; found $\mathrm{C}, 65.75 ; \mathrm{H}$, $6.18 ; \mathrm{N}, 3.12 \%, \mathrm{C}_{48} \mathrm{H}_{54} \mathrm{O}_{2} \mathrm{~N}_{2} \mathrm{~S}_{4} \mathrm{Si}$ requires $\mathrm{C}, 65.86 ; \mathrm{H}, 6.22 ; \mathrm{N}, 3.20 \% ;{ }^{293}[\alpha]_{\mathrm{D}}=+5.0($ $\left.\mathrm{c}=0.2, \mathrm{CHCl}_{3}\right)$.

\section{S,S-Bis(N-(1"'-hydroxyprop-2"'-yl)pyrrolo[3,4-d])tetrathiafulvalene 20.}

A mixture of the bis-protected donor $40(0.85 \mathrm{~g}, 1.0 \mathrm{mmol})$ and tetrabutylammonium fluoride solution (1.0 M in THF, $5.0 \mathrm{ml}, 5.0 \mathrm{mmol})$ in THF $(60 \mathrm{ml})$ was stirred at room temperature for $6 \mathrm{~h}$. After adding water $(5 \mathrm{ml})$, the solvent was removed. The residue was washed with ether and then purified by flash chromatography $\left(\mathrm{SiO}_{2}\right.$, eluting with ethyl acetate:methanol 9:1) to yield a yellow solid (283 mg). The solid was stirred with DCM (20 ml) overnight to give the chiral diol 20 as a yellow solid (193 mg, 49.9\%); m.p. 176$178^{\circ} \mathrm{C}$ (dec.); $\mathrm{R}_{\mathrm{f}}$ (ethyl acetate:methanol 9:1) 0.15; $\delta_{H}\left(400 \mathrm{MHz}, \mathrm{CDCl}_{3}\right) 6.54(4 \mathrm{H}, \mathrm{s}, 4-$ ,4'-,6-,6'-H), $4.08\left(2 \mathrm{H}, \mathrm{m}, 2 \times 2\right.$ ' '-H), 3.67 (4H, m, 2×1'’- $\left.\mathrm{H}_{2}\right), 1.53(2 \mathrm{H}, \mathrm{br}, 2 \times \mathrm{OH}), 1.41$ $\left(6 \mathrm{H}, \mathrm{d}, \mathrm{J} 7.0 \mathrm{~Hz}, 2 \times \mathrm{CH}_{3}\right)$; $\delta_{C}\left(100.6 \mathrm{MHz} \mathrm{CDCl}_{3}\right) 120.4$ (2-,2'-C), 119.3 (3a-,3a'-,6a,6a'-C), $110.6\left(4-, 4\right.$ '-,6-,6'-C), $67.4\left(2 \times 1\right.$ '”-C), $58.4\left(2 \times 2\right.$ '’-C), $17.4\left(2 \times 3\right.$ '”-C); $v_{\max }$ : $3385,1489,1366,1301,1135,1125,1114,1059,1025,992,974,757,606 ; \mathrm{m} / z:$ (EI) $398[\mathrm{M}]^{+}$; found $\mathrm{C}, 48.29 ; \mathrm{H}, 4.44 ; \mathrm{N}, 6.95 \%, \mathrm{C}_{16} \mathrm{H}_{18} \mathrm{~N}_{2} \mathrm{O}_{2} \mathrm{~S}_{4}$ requires $\mathrm{C}, 48.21 ; \mathrm{H}, 4.55$; $\mathrm{N}, 7.03 \% ;{ }^{293}[\alpha]_{\mathrm{D}}=+27.6(\mathrm{c}=0.2, \mathrm{THF})$.

\section{Diastereoisomers of $\quad N$-(1'-Phenyl-ethyl)-2-thioxo-5,6-dihydro-[1,3]dithiolo[4,5- b][1,4]dithiin-5-yl-acetamide, 43 and 44.}

A stirred solution of the acid $\mathbf{4 1}^{30}(2.90 \mathrm{~g}, 10.3 \mathrm{mmol})$ and triethylamine $(1.70 \mathrm{ml}, 12.2$ $\mathrm{mmol})$ in dry THF $(100 \mathrm{ml})$ under a nitrogen atmosphere was cooled to $0{ }^{\circ} \mathrm{C}$ and ethyl 
chloroformate $(1.34 \mathrm{~g}, 12.3 \mathrm{mmol})$ was added. After stirring for $10 \mathrm{~min}$ a solution of $(R)$ (+)-alpha-methylbenzylamine $(2.50 \mathrm{~g}, 20.6 \mathrm{mmol})$ in THF $(10 \mathrm{ml})$ was added. The solution was allowed to warm to room temperature and then stirred overnight. Removal of the solvent and column chromatography (cyclohexane/ethyl acetate 3:1) gave, after elution of unreacted chiral amine, two yellow fractions:

$\left(5 R, 1^{\prime} R\right)$ isomer) $43,(1.12 \mathrm{~g}, 28.3 \%)$, yellow feathery needles, m.p. $135-137{ }^{\circ} \mathrm{C}, \mathrm{R}_{\mathrm{f}}$ (cyclohexane:ethyl acetate 3:1) 0.26; $\delta_{H}\left(400 \mathrm{MHz}, \mathrm{CDCl}_{3}\right) 7.26\left(5 \mathrm{H}, \mathrm{m}, \mathrm{Ar}-\mathrm{H}_{5}\right), 5.94$ $(1 \mathrm{H}, \mathrm{d}, \mathrm{J} 7.7 \mathrm{~Hz}, \mathrm{~N}-H), 5.04(1 \mathrm{H}$, quin, J $7.1 \mathrm{~Hz}, \mathrm{~N}-\mathrm{CH}), 4.11(1 \mathrm{H}, \mathrm{m}, 5-H), 3.34(1 \mathrm{H}$, dd, J 2.8, $\left.13.5 \mathrm{~Hz}, 6-H_{\alpha}\right), 3.06\left(1 \mathrm{H}, \mathrm{dd}, \mathrm{J} 5.3,13.5 \mathrm{~Hz}, 6-H_{\beta}\right), 2.67(2 \mathrm{H}, \mathrm{d}, \mathrm{J} 7.1 \mathrm{~Hz}$, $\left.(\mathrm{O}=\mathrm{C}) \mathrm{CH}_{2}\right), 1.43\left(3 \mathrm{H}, \mathrm{d}, \mathrm{J} 6.8 \mathrm{~Hz}, \mathrm{CH}_{3}\right) ; \delta_{C}\left(100.6 \mathrm{MHz}, \mathrm{CDCl}_{3}\right) 207.65(\mathrm{C}=\mathrm{S}), 167.67$ $(C=\mathrm{O}), \quad 142.47,128.76,127.63 \& 126.09$ (Ar- $\left.C_{6}\right), 122.55 \& 120.85$ (3a-,7a-C), 49.21 $(\mathrm{N}-\mathrm{CH}), 41.39\left(\mathrm{O}=\mathrm{C}-\mathrm{CH}_{2}\right), 38.24(5-C), 34.07(6-C), 21.66\left(\mathrm{CH}_{3}\right) ; v_{\max }: 3144,3072$, 2960, 2888, 1648, 1552, 1500, 1456, 1420, 1372, 1240, 1060; m/z: (CI): 403 $\left(\left[\mathrm{M}+\mathrm{NH}_{4}\right]^{+}\right), 388,387,386\left([\mathrm{M}+\mathrm{H}]^{+}\right), 385,356,312,280 ; \operatorname{HRMS}(\mathrm{CI})$ : found 384.9750, $\mathrm{C}_{15} \mathrm{H}_{15} \mathrm{NOS}_{5}$ requires: $384.9752 ;{ }^{297}[\alpha]_{\mathrm{D}}:+122(\mathrm{c}=0.46, \mathrm{DCM})$.

$\left(5 S, 1^{\prime} R\right)$ isomer $) \quad 44,(1.10 \mathrm{~g}, 27.8 \%)$, yellow plates, m.p. $161-163{ }^{\circ} \mathrm{C}, \quad \mathrm{R}_{\mathrm{f}}$ (cyclohexane:ethyl acetate 3:1) $0.14 ; \quad \delta_{H}\left(400 \mathrm{MHz}, \mathrm{CDCl}_{3}\right) 7.26\left(5 \mathrm{H}, \mathrm{m}, \mathrm{Ar}-\mathrm{H}_{5}\right), 5.84$ $(1 \mathrm{H}, \mathrm{d}, \mathrm{J} 7.4 \mathrm{~Hz}, \mathrm{NH}), 5.05(1 \mathrm{H}$, quin, J 7.1 Hz, N-CH), $4.11(1 \mathrm{H}, \mathrm{m}, 5-H), 3.41(1 \mathrm{H}, \mathrm{dd}$, J $\left.2.7,13.5 \mathrm{~Hz}, 6-H_{\alpha}\right), 3.20\left(1 \mathrm{H}, \mathrm{dd}, \mathrm{J} 5.3,13.5 \mathrm{~Hz}, 6-H_{\beta}\right), 2.71(1 \mathrm{H}, \mathrm{dd}, \mathrm{J}$ 7.1, $15.4 \mathrm{~Hz}$, $\left.(\mathrm{O}=\mathrm{C}) \mathrm{CH}_{\alpha}\right), 2.63\left(1 \mathrm{H}, \mathrm{dd}, \mathrm{J} 7.1,15.4 \mathrm{~Hz},(\mathrm{O}=\mathrm{C}) \mathrm{CH}_{\beta}\right), 1.44\left(3 \mathrm{H}, \mathrm{d}, \mathrm{J} 7.1 \mathrm{~Hz}, \mathrm{CH}_{3}\right)$; $\delta_{\mathrm{C}}$ : $207.63(C=\mathrm{S}), 167.63(C=\mathrm{O}), 142.71,128.74,127.56 \& 126.01$ Ar- $\left.C_{6}\right), 122.62 \& 121.00$ $(3 \mathrm{a}-, 7 \mathrm{a}-C), 49.28(\mathrm{~N}-C \mathrm{H}), 41.42\left(\mathrm{O}=\mathrm{C}-\mathrm{CH}_{2}\right), 38.32(5-C), 33.92(6-C), 21.77\left(\mathrm{CH}_{3}\right)$; $v_{\max }: 3108,2936,2864,1636,1552,1504,1456,1348,1318,1300,1264,1060 ; \mathrm{m} / \mathrm{z}$ : (CI): 403([M+NH$\left.]^{+}\right), 386\left([\mathrm{M}+\mathrm{H}]^{+}\right), 385,387,312,280 ; H R M S(\mathrm{CI})$ found: 384.9756, $\mathrm{C}_{15} \mathrm{H}_{15} \mathrm{NOS}_{5}$ requires: $384.9752 ;{ }^{297}[\alpha]_{\mathrm{D}}:-176(\mathrm{c}=0.39, \mathrm{DCM})$.

\section{(1'R,5R)- N-(1'-Phenyl-ethyl)-(BEDT-TTF)-acetamide 21.}

A solution of thione 43 (573 mg, $1.923 \mathrm{mmol})$ and the unsubstituted oxo compound 45 (620 mg, $3.846 \mathrm{mmol})$ in triethyl phosphite $(10 \mathrm{ml})$ was stirred overnight at $90{ }^{\circ} \mathrm{C}$. After cooling, the volatiles were removed under vacuum and the crude material purified by 
column chromatography (eluting with cyclohexane:ethyl acetate 3:1) to afford the donor 21 (253 mg, $31 \%)$ as an orange-red glassy solid, m.p. 125-127 ${ }^{\circ} \mathrm{C}$ dec.; $\mathrm{R}_{\mathrm{f}}$ (cyclohexane:ethyl acetate 3:1) $0.24 ; \delta_{H}\left(400 \mathrm{MHz}, \mathrm{CDCl}_{3}\right): 7.22\left(5 \mathrm{H}, \mathrm{m}, \mathrm{Ar}-\mathrm{H}_{5}\right), 5.93$ $(1 \mathrm{H}, \mathrm{d}, J$ 7.8 Hz, N-H), $5.03(1 \mathrm{H}$, quin, $J 7.4 \mathrm{~Hz}, \mathrm{~N}-\mathrm{CH}), 4.02(1 \mathrm{H}, \mathrm{m}, 5-H), 3.24(1 \mathrm{H}$, dd, J 3.1, $\left.13.4 \mathrm{~Hz}, 6-H_{\alpha}\right), 3.21\left(4 \mathrm{H}, \mathrm{s}, 5^{\prime}-6^{\prime}-H_{2}\right), 2.94\left(1 \mathrm{H}, \mathrm{dd}, J\right.$ 4.8, $\left.13.3 \mathrm{~Hz}, 6-H_{\beta}\right)$, $2.57\left(2 \mathrm{H}, \mathrm{d}, J 7.2 \mathrm{~Hz},(\mathrm{O}=\mathrm{C}) \mathrm{CH}_{2}\right), 1.42\left(3 \mathrm{H}, \mathrm{d}, J 6.9 \mathrm{~Hz}, \mathrm{CH}_{3}\right) ; \quad \delta_{C}(100.6 \mathrm{MHz}$, $\left.\mathrm{CDCl}_{3}\right): 168.1(C=\mathrm{O}), 142.9,128.7,127.4 \& 126.0$ (Ar- $\left.C_{6}\right), 113.8,113.7,112.7,112.1$, $112.0 \& 111.2\left(6 \mathrm{x} \mathrm{sp}^{2}-C\right), 49.2(\mathrm{~N}-\mathrm{CH}), 41.6\left(\mathrm{O}=\mathrm{C}-\mathrm{CH}_{2}\right), 38.5(5-C), 34.6(6-C), 30.1$ $\left(5^{\prime}-, 6^{\prime}-C\right), 21.8\left(\mathrm{CH}_{3}\right) ; v_{\max }: 3300,2970,2924,1713,1650,1543,1449,1366,1263 ; \mathrm{m} / z$ (CI): $563\left(\left[\mathrm{M}+\mathrm{NH}_{4}\right]^{+}\right), 546\left([\mathrm{M}+\mathrm{H}]^{+}\right), 462,391,279,217 ; \operatorname{HRMS}(\mathrm{CI})$ : found 545.9298, $\left(\mathrm{C}_{20} \mathrm{H}_{19} \mathrm{NOS}_{8}+\mathrm{H}\right)$ requires 545.9305 ; found $\mathrm{C}, 43.85 ; \mathrm{H}, 3.38 ; \mathrm{N}, 2.64 \%, \mathrm{C}_{20} \mathrm{H}_{19} \mathrm{NOS}_{8}$ requires C, 43.87; H, 3.40; N, 2.64\%; ${ }^{293}[\alpha]_{\mathrm{D}}:+2.1(\mathrm{c}=0.147, \mathrm{DCM})$.

\section{(1'R,5S)-N-(1'-Phenyl-ethyl)-(BEDT-TTF)-acetamide 22.}

Following the procedure for 21, thione $44(600 \mathrm{mg}, 1.56 \mathrm{mmol})$ and oxo compound 45 (810 mg, $3.89 \mathrm{mmol})$ in triethyl phosphite (14 ml) afforded the donor 22 (185 $\mathrm{mg}, 46 \%)$ as a pink solid, m.p. $148-158{ }^{\circ} \mathrm{C}$ dec. $\mathrm{R}_{\mathrm{f}}$ (cyclohexane:ethyl acetate $\left.3: 1\right) \quad 0.22 ; \quad \delta_{H}(400$ $\left.\mathrm{MHz} \mathrm{CDCl}_{3}\right) 7.29\left(5 \mathrm{H}, \mathrm{m}, \mathrm{Ar}-H_{5}\right), 6.09(1 \mathrm{H}, \mathrm{d}, \mathrm{J} 7.8 \mathrm{~Hz}, \mathrm{~N}-H), 5.07$ (1H, quin, J 7.3 Hz, N-CH), $4.03(1 \mathrm{H}, \mathrm{m}, 5-H), 3.33$ (1H, dd, J 3.0, $\left.13.3 \mathrm{~Hz}, 6-H_{\alpha}\right), 3.26(4 \mathrm{H}, \mathrm{s}, 5$ '-,6'$\left.H_{2}\right), 3.11\left(1 \mathrm{H}, \mathrm{dd}, \mathrm{J} 4.9,13.3 \mathrm{~Hz}, 6-H_{\beta}\right), 2.66\left(1 \mathrm{H}, \mathrm{dd}, \mathrm{J} 6.8,15.1 \mathrm{~Hz},(\mathrm{O}=\mathrm{C}) \mathrm{C} H_{\alpha}\right), 2.59$ $\left(1 \mathrm{H}, \mathrm{dd}, \mathrm{J} 7.2,15.1 \mathrm{~Hz},(\mathrm{O}=\mathrm{C}) \mathrm{CH}_{\beta}\right), 1.45\left(3 \mathrm{H}, \mathrm{d}, \mathrm{J} 6.8 \mathrm{~Hz}, \mathrm{CH}_{3}\right) ; \delta_{C}\left(100.6 \mathrm{MHz}, \mathrm{CDCl}_{3}\right)$ $168.2(C=\mathrm{O}), 142.6,128.7,127.5 \& 126.1\left(\mathrm{Ar}-C_{6}\right), 113.8,112.6,112.2,111.7 \& 111.3(6$ x sp $\left.{ }^{2}-C\right), 49.1(\mathrm{~N}-C \mathrm{H}), 41.6\left(\mathrm{O}=\mathrm{C}-C_{2}\right), 38.4(5-C), 34.7(6-C), 30.1$ (5'-,6'-C), 21.7 $\left(\mathrm{CH}_{3}\right)$; v $v_{\max }: 3297,3050,2976,2925,1642,1542,1448,1410,1373,1263,1159,1127$, 1018; $m / z: 568\left(\left[\mathrm{M}+\mathrm{NH}_{4}\right]^{+}\right), 546\left([\mathrm{M}+\mathrm{H}]^{+}\right), 443,357,217 ; H R M S(\mathrm{CI})$ found: 545.9299, $\left(\mathrm{C}_{20} \mathrm{H}_{19} \mathrm{NOS}_{8}+\mathrm{H}\right)$ requires: 545.9305; found $\mathrm{C}$, 43.83; H, 3.40; $\mathrm{N}, 2.70 \%, \mathrm{C}_{20} \mathrm{H}_{19} \mathrm{NOS}_{8}$ requires C, 43.92; $\mathrm{H}, 3.40 ; \mathrm{N}, 2.64 \% ;{ }^{297}[\alpha]_{\mathrm{D}}:-68\left(\mathrm{c}=0.17, \mathrm{CH}_{2} \mathrm{Cl}_{2}\right)$. 


\section{Dimethyl trans-5,6-dihydro-2-thioxo-1,3-dithiolo[4,5-b]dithiin-5,6-diacetate 46.}

A suspension of trithione $41(3.10 \mathrm{~g}, 15.8 \mathrm{mmol})$ and dimethyl $E$-hex-3-enedioate $(2.75 \mathrm{~g}, 16.0 \mathrm{mmol})$ in toluene $(100 \mathrm{~mL})$ was heated to reflux for $48 \mathrm{~h}$ under nitrogen. After evaporation of toluene, the residue was dissolved in chloroform, warmed with charcoal for $10 \mathrm{~min}$, filtered and evaporated. The residue was purified by flash chromatography $\left(\mathrm{SiO}_{2}\right.$, eluting with cyclohexane:ethyl acetate 2:1), and the main fraction evaporated and stirred with hexane for 2 days to remove alkene starting material. Filtration and evaporation solution afforded thione $46(4.41 \mathrm{~g}, 75.8 \%)$ as a yellow powder; m.p. $90-92{ }^{\circ} \mathrm{C} ; \mathrm{R}_{\mathrm{f}}$ (cyclohexane:ethyl acetate $\left.3: 1\right) \quad 0.36 ; \delta_{H}\left(400 \mathrm{MHz}, \mathrm{CDCl}_{3}\right)$ : $3.83(2 \mathrm{H}, \mathrm{m}, 5-, 6-\mathrm{H}), 3.73\left(6 \mathrm{H}, \mathrm{s}, 2 \times \mathrm{OCH}_{3}\right), 2.86\left(4 \mathrm{H}, \mathrm{m}, 5-, 6-\mathrm{CH}_{2}\right) ; \delta_{C}(100.6 \mathrm{MHz}$, $\left.\mathrm{CDCl}_{3}\right): 206.9(C=\mathrm{S}), 170.3(2 \times C=\mathrm{O}), 118.8(3 \mathrm{a}-, 7 \mathrm{a}-C), 52.3\left(2 \times \mathrm{OCH}_{3}\right), 40.9(2 \times 5-, 6-$ $\mathrm{CH}_{2}$ ), 40.7 (5-,6-C); v $v_{\max }$ : 2949, 1719, 1486, 1437, 1369, 1249, 1206, 1158, 1062, 1031, 1016, 973, 921, 886, 810, 574, 516; found $\mathrm{C}, 35.91 ; \mathrm{H}, 3.23 \%, \mathrm{C}_{11} \mathrm{H}_{12} \mathrm{O}_{4} \mathrm{~S}_{5}$ requires $\mathrm{C}$, $35.85 ; \mathrm{H}, 3.28 \%$.

\section{Dimethyl trans-5,6-dihydro-2-oxo-1,3-dithiolo[4,5-b]dithiin-5,6-diacetate 47.}

From 46 (1.84 g, $5.03 \mathrm{mmol})$ using Method A afforded 47 (1.67 g, 94.3\%) as a pale orange solid; m.p. $79-81{ }^{\circ} \mathrm{C} ; \mathrm{R}_{\mathrm{f}}$ (cyclohexane:ethyl acetate $\left.3: 1\right) \quad 0.40 ; \quad \delta_{H}(400 \mathrm{MHz}$, $\left.\mathrm{CDCl}_{3}\right): 3.75(2 \mathrm{H}, \mathrm{m}, 5-, 6-H), 3.67\left(6 \mathrm{H}, \mathrm{s}, 2 \times \mathrm{OCH}_{3}\right), 2.87\left(4 \mathrm{H}, \mathrm{m}, 5-, 6-\mathrm{CH}_{2}\right) ; \delta_{C}(100.6$ $\left.\mathrm{MHz}, \mathrm{CDCl}_{3}\right): 170.5(C=\mathrm{O}), 109.5(3 \mathrm{a}-, 7 \mathrm{a}-C), 52.2\left(2 \times \mathrm{OCH}_{3}\right), 42.0(5-, 6-C), 40.9(2 \times$ 5-,6- $\left.\mathrm{CH}_{2}\right)$; vmax: 3001, 2944, 1733, 1716, 1684, 1647, 1626, 1505, 1435, 1398, 1363, 1258, 1204, 1170, 1150, 1055, 978, 927, 778, 554; found C, 37.38; H, 3.34\%, $\mathrm{C}_{11} \mathrm{H}_{12} \mathrm{O}_{5} \mathrm{~S}_{4}$ requires $\mathrm{C}, 37.49 ; \mathrm{H}, 3.42 \%$.

\section{Dimethyl vic-trans-BEDT-TTF-diacetate 48.}

From 47 (1.97 g, $5.61 \mathrm{mmol})$ and 29 (3.14 g, $14.0 \mathrm{mmol})$ and trimethyl phosphite (60 $\mathrm{ml}$ ) using Method $\mathbf{C}$ gave the trans diester 48, as an orange solid (1.64 g, 55.3\%,); m.p. $136-138^{\circ} \mathrm{C} ; \mathrm{R}_{\mathrm{f}}($ cyclohexane:ethyl acetate $2: 1) \quad 0.62 ; \delta_{H}\left(400 \mathrm{MHz}, \mathrm{CDCl}_{3}\right): 3.73(2 \mathrm{H}$, m, 5-,6- $H$ ), $3.69\left(6 \mathrm{H}, \mathrm{s}, 2 \times \mathrm{OCH}_{3}\right), 3.25\left(4 \mathrm{H}, \mathrm{s}, 5^{\prime}-, 6^{\prime}-\mathrm{H}_{2}\right), 2.77(4 \mathrm{H}, \mathrm{m}, 2$ x 5-,6-CH2); 
$\delta_{C}\left(100.6 \mathrm{MHz}, \mathrm{CDCl}_{3}\right): 170.6(2 \times C=\mathrm{O}), 113.8,112.0,110.3,110.0\left(2-, 2{ }^{\prime}-, 3 \mathrm{a}-, 3 \mathrm{a} \mathbf{y}^{\prime}\right.$, 7a-, 7a'-C), $52.1\left(2 \times \mathrm{OCH}_{3}\right), 41.0\left(2 \times 5-, 6-\mathrm{CH}_{2}\right), 40.7(5,6-C), 30.1$ (5'-,6'-C); $v_{\max }$ : 2956, 2918, 1732, 1436, 1414, 1367, 1338, 1308, 1288, 1258, 1239, 1214, 1191, 1138, 1152, $1093,1031,1011,988,912,873,848,772$; found $\mathrm{C}, 36.41 ; \mathrm{H}, 2.95 \%, \mathrm{C}_{16} \mathrm{H}_{16} \mathrm{O}_{4} \mathrm{~S}_{8}$ requires $\mathrm{C}, 36.34 ; \mathrm{H}, 3.05 \%$.

\section{vic-trans-BEDT-TTF-di(acetic acid) 23.}

Diester 48 (200 mg, $0.38 \mathrm{mmol}$ ) and potassium hydrogen carbonate (300 mg, $3.00 \mathrm{mmol}$ ) were dissolved in a mixture of methanol $(9 \mathrm{ml})$, THF $(10 \mathrm{ml})$ and water $(5 \mathrm{ml})$ and refluxed together for $2 \mathrm{~h}$. The filtered mixture was evaporated and extracted between water and dichloromethane. The aqueous layer was carefully acidified with $1 \mathrm{M}$ hydrochloric acid and the suspension produced stirred in an ice bath for $1 \mathrm{~h}$ and filtered to give a product with a 1:1 composition of $\mathbf{2 3}$ and its monopotassium salt, as a yellow brown powder $(80 \mathrm{mg}, 41 \%)$ which was insoluble in organic solvents; m.p. $170-173{ }^{\circ} \mathrm{C}$ (dec.); vmax: 2916 br, 1702, 1437, 1404, 1288, 1248, 1222, 1163, 1001, 884. Found C: $32.7 \quad \mathrm{H}: 2.1 \% \quad \mathrm{C}_{14} \mathrm{H}_{12} \mathrm{O}_{4} \mathrm{~S}_{8} . \mathrm{C}_{14} \mathrm{H}_{11} \mathrm{O}_{4} \mathrm{~S}_{8} \mathrm{~K}$ requires $\mathrm{C}: 32.3 \mathrm{H}: 2.2 \%$.

\section{exo- 5,8-Methano-4a,5,6,7,8,8a-hexahydro-1,3-dithiolo[4,5- b]benzo-1,4- dithiin-2-thione 49.}

Norbornene (4.00 g, $42.4 \mathrm{mmol})$ and trithione $41(8.30 \mathrm{~g}, 42.4 \mathrm{mmol})$ were refluxed together in toluene $(500 \mathrm{ml})$ for $27 \mathrm{~h}$ and filtered. The filtrate was evaporated to dryness and the residue refluxed in methanol $(50 \mathrm{ml})$ for $30 \mathrm{~min}$. After cooling to room temperature, filtration gave thione 49 (11.69 g, 95\%) as thin yellow plates, m.p. 172-174 ${ }^{\circ} \mathrm{C} ; \mathrm{R}_{\mathrm{f}}$ (cyclohexane: ethyl acetate 4:1) $0.78 ; \delta_{H}\left(400 \mathrm{MHz}, \mathrm{CDCl}_{3}\right): 3.39(2 \mathrm{H}, \mathrm{s}, 4 \mathrm{a}-, 8 \mathrm{a}-$ H), 2.37 (3H, br, 5-,8-,10 $\left.\alpha_{\alpha^{-}} H\right), 1.66\left(2 \mathrm{H}, \mathrm{d}^{*}, \mathrm{~J} 8.8 \mathrm{~Hz}, 6_{\alpha^{-}}, 7_{\alpha^{-}}-H\right), 1.33(1 \mathrm{H}, \mathrm{d}, \mathrm{J} 10.8 \mathrm{~Hz}$, $\left.10_{\beta}-H\right), \quad 1.27\left(2 \mathrm{H}, \mathrm{d}^{*}, \mathrm{~J} 8.8 \mathrm{~Hz}, 6_{\beta}-7_{\beta}-H\right)$ *some further coupling; $\delta_{C}(100.6 \mathrm{MHz}$, $\left.\mathrm{CDCl}_{3}\right)$ : $209.9(C=\mathrm{S}), 136.5(3 \mathrm{a}-, 9 \mathrm{a}-C), 60.3(4 \mathrm{a}-, 8 \mathrm{a}-C), 44.3$ (5-,8-C), 35.3 (10-C), $29.1(6-, 7-C)$; v $v_{\max }$ : 2951, 2870, 1466, 1449, 1300, 1180, 1145, 1057, 1005, 928, 887, 783, 510, 492, 465, 448; found: $\mathrm{C}, 41.29 ; \mathrm{H}, 3.43 \%, \mathrm{C}_{10} \mathrm{H}_{10} \mathrm{~S}_{5}$ requires: $\mathrm{C}, 41.35 ; \mathrm{H}$, $3.47 \%$. 


\section{Dimethyl trans-exo-(cyclopentan-1',3"'-BEDT-TTF-5,6-diacetate diastereomers 50- 51.}

Oxo compound 47 (1.50 g, $4.26 \mathrm{mmol})$ and thione 49 (3.14 g, $10.81 \mathrm{mmol})$ in trimethyl phosphite following Method $\mathbf{C}$ gave, after chromatography, a 1:1 mixture of $\mathbf{5 0}$ and $\mathbf{5 1}$ $(0.90 \mathrm{~g}, 35.7 \%$,$) as an orange solid, m.p. 164-168{ }^{\circ} \mathrm{C} ; \mathrm{R}_{\mathrm{f}}$ (cyclohexane:ethyl acetate 4:1) 0.34; two diastereomers showing very similar ${ }^{1} \mathrm{H} \&{ }^{13} \mathrm{C}$ NMR signals: $\delta_{H}(400 \mathrm{MHz}$, $\left.\mathrm{CDCl}_{3}\right) 3.73(2 \mathrm{H}, \mathrm{m}, 5-, 6-\mathrm{H}), 3.66$ and $3.56\left(6 \mathrm{H}, \mathrm{s}, 2 \mathrm{xOCH}_{3}, 2\right.$ isomers), $3.32(2 \mathrm{H}, \mathrm{s}$, 5'-,6'-H), $2.75\left(4 \mathrm{H}, \mathrm{m}, 5,6-\mathrm{CH}_{2} \mathrm{CO}\right), 2.32\left(2 \mathrm{H}, \mathrm{s}, 1\right.$ ' '-,3' '-H), $2.30\left(1 \mathrm{H}, \mathrm{d}, \mathrm{J} 11 \mathrm{~Hz}, 2^{\prime}{ }^{\prime}{ }_{\alpha^{-}}\right.$ $H), 1.61\left(2 \mathrm{H}, \mathrm{d}, \mathrm{J} 8 \mathrm{~Hz}, 4{ }^{\prime \prime}{ }_{\alpha^{-}}, 5{ }^{\prime}{ }_{\alpha^{-}} H\right), 1.24\left(1 \mathrm{H}, \mathrm{d}, \mathrm{J} 11 \mathrm{~Hz}, 2{ }^{\prime}{ }^{-}-H\right), 1.23(2 \mathrm{H}, \mathrm{d}, \mathrm{J} 8 \mathrm{~Hz}$, 4" $\left.\beta^{-}, 5{ }^{\prime}{ }_{\beta}-H\right) ; \delta_{C}\left(\mathrm{CDCl}_{3}\right): 170.7(2 \times C=\mathrm{O}), 126.9$ (3a'-,7a'-C), 112.7, 110.7, 110.4, 108.5 (2-,2'-,3a-,7a-C), 59.7 (5'-,6'-C), $52.2 \& 52.1\left(2 \times \mathrm{OCH}_{3}\right), 44.3,41.5,40.8,40.2$ (5-,6-C,

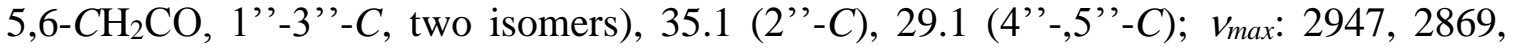
1729, 1435, 1396, 1357, 1300, 1215, 1197, 1165, 1143, 1003, 971, 920, 893, 877, 771, 651, 603, 493; m/z: (EI) 528 [M] ${ }^{+}$; HRMS (ES, with ammonium acetate) found: 594.9351, $[\mathrm{M}+\mathrm{H}]^{+}, \mathrm{C}_{21} \mathrm{H}_{22} \mathrm{O}_{4} \mathrm{~S}_{8}+\mathrm{H}$ requires: 594.9357; found $\mathrm{C}, 42.50 ; \mathrm{H}, 3.56 \%, \mathrm{C}_{21} \mathrm{H}_{22} \mathrm{O}_{4} \mathrm{~S}_{8}$ requires $\mathrm{C}, 42.40 ; \mathrm{H}, 3.73 \%$.

\section{X-ray Crystallography.}

Crystal structures were measured using MoK $\alpha$ radiation at $120 \mathrm{~K}$, solved with SHELXS97 and refined with SHELXL-97 $7^{34}$ using the X-SEED interface. ${ }^{35}$ Molecular illustrations are made with ORTEP- $3^{36}$ and Mercury ${ }^{37}$ using POVRAY ${ }^{38}$ Data is deposited at the Cambridge Crystallographic Data Centre, 12 Union Road, Cambridge, CB2 1EZ with reference numbers CCDC 924767 - 924772.

Crystal data for 15: $\mathrm{C}_{18} \mathrm{H}_{28} \mathrm{O}_{4} \mathrm{~S}_{8}, \mathrm{M}_{\mathrm{r}}=564.88$, orthorhombic, $\mathrm{a}=9.7257(3), \mathrm{b}=$ 9.8612(4), $\mathrm{c}=26.3649(11) \AA, \mathrm{V}=2528.58(17) \AA^{3}, \mathrm{Z}=4, \mathrm{P} 2{ }_{1} 2_{1} 2_{1}, \mathrm{D}_{\mathrm{c}}=1.48 \mathrm{~g} \mathrm{~cm}^{-3}$, $\mu(\mathrm{MoK} \alpha)=0.073 \mathrm{~mm}^{-1}, \mathrm{~T}=120(2) \mathrm{K}, 5533$ unique reflections, 4269 with $\mathrm{F}>4 \sigma(\mathrm{F})$, $\mathrm{R}=0.049, \mathrm{w} R=0.090$. 
Crystal data for 44: $\mathrm{C}_{15} \mathrm{H}_{15} \mathrm{NOS}_{5}, \mathrm{M}_{\mathrm{r}}=385.58$, monoclinic, $\mathrm{a}=5.1301(3), \mathrm{b}=$ 9.2119(5), $\mathrm{c}=17.9448(10) \AA, \alpha=90.0, \beta=94.715(5), \gamma=90.0^{\circ}, \mathrm{V}=845.715(5) \AA^{3}$, $\mathrm{Z}=2, \mathrm{P} 2{ }_{1}, \mathrm{D}_{\mathrm{c}}=1.52 \mathrm{~g} \mathrm{~cm}^{-3}, \mu(\mathrm{MoK} \alpha)=0.685 \mathrm{~mm}^{-1}, \mathrm{~T}=120(2) \mathrm{K}, 3866$ unique reflections, 3703 with $\mathrm{F}>4 \sigma(\mathrm{F}), \mathrm{R}=0.033$, wR $=0.088$, Flack parameter: 0.02(8).

Crystal data for 49: $\mathrm{C}_{10} \mathrm{H}_{10} \mathrm{~S}_{5}, \mathrm{M}_{\mathrm{r}}=290.48$, monoclinic, $\mathrm{a}=6.3435(1) \quad \mathrm{b}=7.3999(2)$ $\mathrm{c}=12.5755(4) \AA, \quad \beta=90.915(2)^{\mathrm{o}}, \mathrm{V}=590.23 \AA^{3}, \mathrm{Z}=2, \mathrm{P} 2_{1}, \mathrm{D}_{\mathrm{c}}=1.634 \mathrm{~g} \mathrm{~cm}^{-3}$, $\mu(\mathrm{MoK} \alpha)=0.94 \mathrm{~cm}^{-1}, \mathrm{~T}=120(2) \mathrm{K}, 2488$ unique reflections, 2415 with $\mathrm{F}>4 \sigma(\mathrm{I}), \mathrm{R}=$ $0.042, \mathrm{wR}=0.108$.

Crystal data for (16) $\left.{ }_{4}\left[\mathrm{Fe}_{2} \text { (oxalate) }\right)_{5}\right]: 4 \mathrm{C}_{14} \mathrm{H}_{18} \mathrm{O}_{2} \mathrm{~S}_{8} \cdot \mathrm{C}_{10} \mathrm{O}_{20} \mathrm{Fe}_{2}, \mathrm{M}_{\mathrm{r}}=2450.86$, monoclinic, $\mathrm{a}=13.8685(4), \mathrm{b}=21.8745(8), \mathrm{c}=15.4879(5) \AA, \beta=100.678(2)^{\mathrm{o}}, \mathrm{V}=4617.1(3) \AA^{3}$, $\mathrm{Z}=2, \mathrm{P} 2{ }_{1}, \mathrm{D}_{\mathrm{c}}=1.76 \mathrm{~g} \mathrm{~cm}^{-3}, \mu(\mathrm{MoK} \alpha)=1.114 \mathrm{~mm}^{-1}, \mathrm{~T}=120(2) \mathrm{K}, 19353$ unique reflections, 14466 with $\mathrm{F}>4 \sigma(\mathrm{F}), \mathrm{R}=0.071$, w $\mathrm{R}=0.136$.

Crystal data for 16.TCNQ-F $\mathrm{C}_{4} \mathrm{C}_{14} \mathrm{H}_{18} \mathrm{O}_{2} \mathrm{~S}_{8} . \mathrm{C}_{12} \mathrm{~N}_{4} \mathrm{~F}_{4}, \mathrm{M}_{\mathrm{r}}=750.92$, triclinic, $\mathrm{a}=$ 8.8930(2), b = 12.4995(2), $\mathrm{c}=13.9897(3) \AA, \alpha=89.2960(10), \beta=74.2240(10), \gamma=$ 86.8580(10) $)^{\mathrm{o}}, \mathrm{V}=1494.24(5) \AA^{3}, \mathrm{Z}=2, \mathrm{P} 1, \mathrm{D}_{\mathrm{c}}=1.67 \mathrm{~g} \mathrm{~cm}^{-3}, \mu(\mathrm{MoK} \alpha)=0.066 \mathrm{~mm}^{-1}$, $\mathrm{T}=120(2) \mathrm{K}, 13037$ unique reflections, 11743 with $\mathrm{F}>4 \sigma(\mathrm{F}), \mathrm{R}=0.033$, wR $=0.081$.

Crystal data for 18. $\mathrm{I}_{3}: \mathrm{C}_{14} \mathrm{H}_{18} \mathrm{O}_{4} \mathrm{~S}_{8} . \mathrm{I}_{3}, M_{\mathrm{r}}=887.46$, monoclinic, $a=19.1095(7), b=$ 10.1013(3), $c=13.8161(6) \AA, \quad \beta=110.103(4)^{\mathrm{o}}, V=2504.45(16) \AA^{3}, Z=4, C 2, D_{\mathrm{c}}$ $=2.35 \mathrm{~g} \mathrm{~cm}^{-3}, \mu=4.43 \mathrm{~mm}^{-1}, T=150 \mathrm{~K}, 3845$ unique reflections $\left(\mathrm{R}_{\text {int }}=0.0249\right), 3282$ with $F^{2}>2 \sigma, R\left(F, F^{2}>2 \sigma\right)=0.038, R_{\mathrm{w}}\left(F^{2}\right.$, all data $)=0.084$.

\section{Conductivity measurements.}

Two-probe DC transport measurements were made on several crystals of

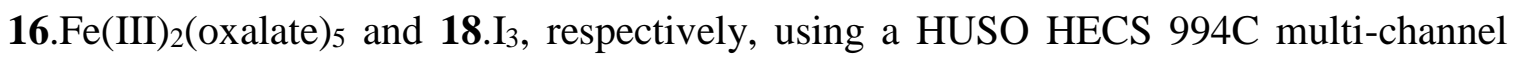
conductometer. Gold wires (15 $\mu \mathrm{m}$ diameter) were attached to the crystal, and the attached wires were connected to an eight-pin integrated circuit plug with gold conductive cement. 


\section{Acknowledgements.}

We thank the EPSRC for grant EP/C510488/1 and for a studentship (ACB), the UK Higher Education Innovation Fund for support (SJK), the Libyan Ministry of Higher Education and Al-Mergheb University for a PhD scholarship (IA), the EPSRC National Crystallography Service for datasets, and the EPSRC Mass Spectrometry Service for measurements. We thank the United Kingdom Chemical Database Service ${ }^{39}$ for access to the Cambridge Structural Database ${ }^{40}$. The work has benefited from support from ESF COST action D35. We thank Brian O'Neill and Peter Moore for construction of constant current sources.

\section{References.}

1. a) Ferraris, J.; Cowan, D.O.; Walatka Jnr., V.V.; Perlstein, J.H. J. Am. Chem. Soc., 1973, 95, 948-949; b) Coleman, L.B.; Cohen, M.J.; Sandman, D.J.; Yamagishi, F.G.; Garito, A.F.; Heeger, A. Solid State Commun., 1973, 12, 1125 1132; c) Wudl, F. Acc. Chem. Res., 1984, 17, 227-232.

2. a) Day, P. Compt. Rend. Chim., 2003, 6, 301-308; b) Mori, H. Opt. Sci. Eng., 2008, 133, 263-285; c) Singleton, J. J. Solid State Chem., 2002, 168, 675-689.

3. a) Herranz, M.; Sanchez, L.; Martin, N. Phosph., Sulf. Silic. Rel. Elem., 2005, 180, 1133-1148; b) Bendikov, M.; Wudl, F.; Perepichka, D.F. Chem. Rev., 2004, 104, 4891-4946; c) Bryce, M.R.; Davenport, W.; Goldenberg, L.M.; Wang, C. Chem. Commun., 1998, 945-952.

4. a) Wallis, J.D.; Griffiths, J.-P. J. Mater. Chem., 2005, 15, 347-365; b) Brown, R.J.; Brooks, A.C.; Griffiths, J.-P.; Vital, B.; Day, P.; Wallis, J.D. Org. Biomol. Chem., 2007, 5, 3172-3182.

5. a) Canevet, D.; Sallé, M.; Zhang, G. ; Zhang, D.; Zhu, D. Chem. Commun., 2009, 2245-2269; b) Bryce, M.R. J. Mater. Chem., 2000, 10, 589-598.

6. Asakawa, M.; Ashton, P.R.; Balzani, V.; Credi, A.; Hamers, C.; Mattersteig, G.; Montalti, M.; Shipway, A.N.; Spencer, N.; Stoddart, J.F.; Tolley, M.S.; Venturi, M.; White, A.J. P.; Williams, D. J. Angew. Chem. Int. Ed., 1998, 37, 333-337.

7. Lyskawa, J.; Canevet, D.; Allain, M.; Sallé, M. Tetrahedron Lett., 2010, 51, 5868-5872. 
8. $\quad$ Mas-Torrent, M.; Hadley, P.; Bromley, S.T.; Veciana, J.; Rovira, C.; Ed. Fitzgerald, B.M. Transistors, 2010, 175-189.

9. Nielsen, M.B. Phosph., Sulf. Silic. Rel. Elem., 2011, 186, 1055-1073.

10. a) Danila,I.; Riobe, F.; Piron, F.; Puigmarti-Luis, J.; Wallis, J.D.; Linares, M.; Agren, H.; Beljonne, D.; Amabilino, D.B.; Avarvari, N. J. Am. Chem. Soc., 2011, 133, 8344-8353; b) Danila, I.; Riobe, F.; Puigmarti-Luis, J.; Perez del Pino, A.; Wallis, J.D.; Amabilino, D.B.; Avarvari, N. J. Mater. Chem., 2009, 19, 4495-4504.

11. a) Krstic, V.; Roth, S.; Burghard, M.; Kern, K.; Rikken, G.L.J.A. J. Chem. Phys. 2002, 117, 11315-11319; b) Krstic, V.; Rikken, G.L.J.A. Chem. Phys. Lett., 2002, 364, 51-56; c) Rikken, G.L.J.A.; Folling, J.; Wyder, P. Phys. Rev. Lett., 2001, 87, 236602/1-4.

12. a) Amabilino, D.B.; Veciana, J. Top. Curr. Chem., 2006, 26, 253-302; b) Perruchas, S.; Boubekeur, K.; Batail, P. Cryst. Growth Design, 2005, 5, 15851596; c) Giffard, M.; Pilet, G.; Allain, M.; Hudhomme, P.; Mabon, G.; Levillain, E.; Gorgues, A.; Riou, A. Chem. Commun., 2001, 2722-2723; d) Li, H.; Zhang, D.; Zhang, B.; Yao, Y.; Xu, W.; Zhu, D.; Wang, Z. J. Mater. Chem., 2000, 10, 2063-2067; e) Heuze, K.; Fourmigue, M.; Batail, P.; Canadell, E.; AubanSenzier, P. Chem. Eur. J., 1999, 5, 2971-2976.

13. Krivickas, S.J.; Ichikawa, A.; Takahashi, K.; Tajima, H.; Wallis, J.D.; Mori, H. Synth. Metals, 2011, 161, 1563-1565.

14. a) Coronado, E.; Galán-Mascarós, J.R.; Coldea, A.I.; Goddard, P.; Singleton, J.; Wallis, J.D.; Coles, S.J.; Alberola, A. J. Am. Chem. Soc., 2010, 132, 9271-9273; b) Chas, M.; Lemarié, M.; Gulea, M.; Avarvari, N. Chem. Commun., 2008, 220224 ; c) Chas, M.; Riobé, F.; Sancho, R.; Minguíllon, C.; Avarvari, N. Chirality, 2009, 21, 818-825.

15. a) Réthoré, C.; Avarvari, N.; Canadell, E.; Auban-Senzier, P.; Fourmigué, M. J. Am. Chem. Soc., 2005, 127, 5748-5749; b) Réthoré, C.; Madalan, A.; Fourmigué, M.; Canadell, E.; Lopes, E.B.; Almeida, M.; Clerac, R.; Avarvari, N. New J. Chem., 2007, 31, 1468-1483.

16. Yang, S.; Brooks, A.C.; Martin, L.; Day, P.; Li, H.; Horton, P.; Male, L.; Wallis, J.D. CrystEngComm., 2009, 11, 993-996.

17. Yang, S.; Brooks, A.C.; Martin, L.; Day, P.; Pilkington, M.; Clegg, W.; Harrington, R.W.; Russo, L.; Wallis, J.D. Tetrahedron, 2010, 66, 6977-6989. 
18. a) Gómez, R.; Segura, J. L.; Martin, N. Org. Lett., 2000, 2, 1585-1587; b) Gómez, R.; Segura, J. L.; Martin, N. J. Org. Chem., 2000, 65, 7566-7574; c) Saad, A.; Jeannin, O.; Fourmigué, M. New J. Chem., 2011, 35, 1004-1010.

19. Zhou, Y.; Zhang, D.; Zhu, L.; Shuai, Z.; Zhu, D. J. Org. Chem., 2006, 71, 21232130.

20. Gomar-Nadal, E.; Rovira, C.; Amabilino, D. B. Tetrahedron, 2006, 62, 33703379.

21. Kitamura, T.; Nakaso, S.; Mizoshita, N.; Tochigi, Y.; Shimomura, T.; Moriyama, M.; Ito, K.; Kato, T. J. Am. Chem. Soc., 2005, 127, 14769-14775.

22. a) Coronado, E.; Galan-Mascaros, J.R. J. Mater. Chem., 2005, 15, 66-74; b) Avarvari, N.; Wallis, J.D. J. Mater. Chem., 2009, 19, 4061-4076.

23. a) Leurquin, F.; Ozturk, T.; Pilkington, M.; Wallis, J.D. J. Chem. Soc., Perkin Trans 1, 1997, 3173-3178; b) Brown, R.J.; Brooks, A.C.; Griffiths, J.-P.; Vital, B.; Day, P.; Wallis, J.D. Org. Biomol. Chem., 2007, 5, 3172-3182.

24. a) Booth, S.; Wallace, E. N. K.; Singhal, K.; Bartlett, P.N.; Kilburn, J.D. J. Chem. Soc., Perkin Trans 1, 1998, 1467-1474; b) Alea, G. V.; Janairo, G. C.; Kilburn, J.D. Philipp. J. Sci., 2007, 136, 33-43.

25. a) Svenstrup, N.; Becher, J. Synthesis, 1995, 215-325; b) Wang, C.; Batsanov, A.S.; Bryce, M.R.; Howard, J.A.K. Synthesis, 1998, 1615-1618.

26. Further details are supplied in the Supplementary Material.

27. a) Rashid, S.; Turner, S.S.; Day, P.; Light, M.E.; Hursthouse, M.B.; Guionneau, P. Synth. Met., 2001, 120, 985-986; b) Coronado, E.; Galan-Mascaros, J.R.; Gomez-Garcia, C.J. J. Chem. Soc. Dalton Trans., 2000, 205-210.

28. Jeppesen, J.O.; Becher, J. Eur. J. Org. Chem. 2003, 3245-3266.

29. Jeppesen, J.O.; Takimiya, K.; Jensen, F.; Brimert, T.; Nielsen, K.; Thorup, N.; Becher, J. J. Org. Chem., 2000, 65, 5794-5805.

30. Brickmann, K.; Yuan, Z.-Q.; Sethson, I.; Somfai, P.; Kihlberg, J. Chem. Eur. J., 1999, 5, 2241-2253.

31. Brown, R. J.; Cameresa, G.; Griffiths, J.-P.; Day, P.; Wallis, J.D. Tetrahedron Lett. 2004, 45, 5103-5107.

32. Guionneau, P.; Kepert, C.J. ; Bravic, G.; Chasseau, D.; Truter, M.R.; Kurmoo, M.;Day, P. Synth. Met., 1997, 86, 1973-1974. 
33. a) Aktoudianakis, E.; Celebi, A.A.; Du, Z.; Jabri, S.Y.; Jin, H.; Kim, C.U.; Li, J.; Metobo, S.E.; Mish, M.R.; Phillips, B.W.; Saugier, J.H.; Yang, Z.-Y.; Zonte, C.S. PCT Int. Appl. (2010), WO 2010011959 A1 20100128; b) Cassel, S.; Debaig, C. ; Benvegnu, T.; Chaimbault, P.; Lafosse, M.; Plusquellec, D.; Rollin, P. Eur. J. Org. Chem., 2001, 875-896.

34. Sheldrick, G.M. Acta Crystallogr. Sect. A, 2008, 64, 112-122.

35. Barbour, L.J. J. Supramol. Chem. 2001, 1, 189-193.

36. Farrugia, L.J. J. Appl. Crystallog., 1997, 30, 565-566.

37. Macrae, C.F.; Edgington, P.R.; McCabe, P.; Pidcock, E.; Shields, G.P.; Taylor, R.; Towler, M.; van de Streek, J. J. Appl. Crystallogr. 2006, 39, 453-457.

38. Persistence of Vision Pty. Ltd. (2004). Persistence of Vision (TM) Raytrace Persistence of Vision Pty. Ltd., Williamstown, Victoria, Australia, http://www.povray.org/.

39. The United Kingdom Chemical Database Service, Fletcher, D.A.; McMeeking, R.F.; Parkin, D.J. Chem. Inf. Comput. Sci., 1996, 36, 746-749.

40. Allen, F.H. Acta Crystallogr. Sect. B, 2002, 58, 380-388.

\section{Graphical Abstract.}
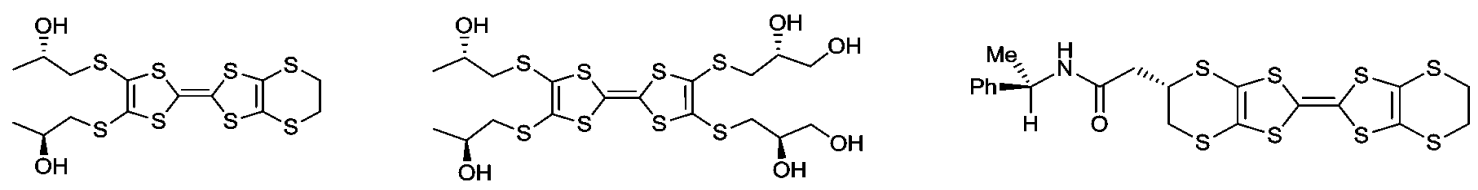